\title{
Development of Bio-Cutting Fluid (Cirtullus lanatus) and its Performance Assessment on the Machining of AISI 1525 Steel Using Taguchi Technique and Grey Relational Analysis
}

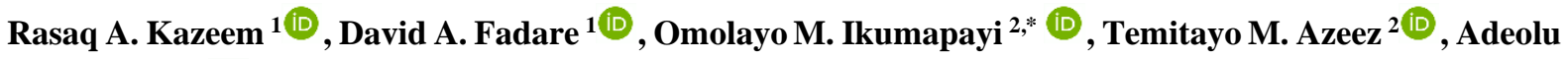 \\ A. Adediran 3 (D)

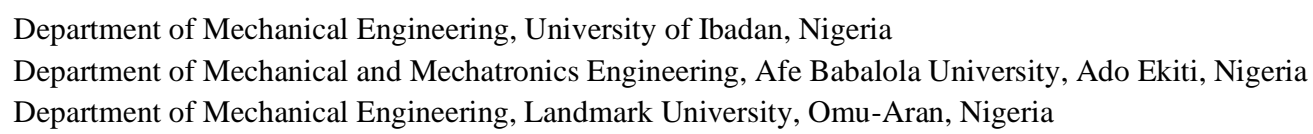

Scopus Author ID 57195937913

Received: 8.07.2021; Revised: 15.08.2021; Accepted: 20.08.2021; Published: 18.10.2021

\begin{abstract}
Due to traditional mineral oils' adverse environmental and health effects, vegetable oil-based cutting fluids have become widely attractive in machining. The majority of the vegetable oils used in literature are edible and may compete with human consumption if promoted, thereby making it more expensive as cutting fluids. However, few studies have been carried out on the applicability of lesserknown vegetable oils as cutting fluids. This study, therefore, aims at investigating the efficiency of lesser-known vegetable oil (watermelon oil) as a machining cutting fluid. The developed watermelon oil was mechanically compared to the traditional mineral oil in turning AISI 1525 steel based on cutting temperature, surface roughness, and chip formation mode. The experiment depended on Taguchi plan with $\mathrm{L}_{9}$ orthogonal arrangement utilizing feed rate, depth of cut, and cutting speed as critical input parameters. Moreover, the grey relational analysis optimization approach was employed to analyze the parameter impacts and achieve the best possible cutting parameters. The optimization showed that the best combinations of cutting parameters for cutting speed, feed rate, and depth of cut were ( $355 \mathrm{rev} / \mathrm{min}$, $0.1 \mathrm{~mm} / \mathrm{rev}$ and $1 \mathrm{~mm}$ ), and (355 rev/min, $0.1 \mathrm{~mm} / \mathrm{rev}$, and $1.25 \mathrm{~mm}$ ) for watermelon and mineral oils, respectively.
\end{abstract}

Keywords: AISI 1525 steel; watermelon oil; cutting temperature; cutting fluid; surface roughness; mineral oils.

(C) 2021 by the authors. This article is an open-access article distributed under the terms and conditions of the Creative Commons Attribution (CC BY) license (https://creativecommons.org/licenses/by/4.0/).

\section{Introduction}

Metal cutting fluids are added to reduce friction and wear between two moving parts (i.e., workpiece and cutting instrument) and thereby improve the tool life expectant and surface quality of the material being machined. Metal cutting fluids also significantly reduce strength and energy consumption; they further wash off the chips, cocool Mineral-based cutting fluids are approximately $85 \%$ of the metal cutting fluids used worldwide [2]. Mineral-based cutting fluids have numerous benefits but are adversely affected by health and environmental problems. Studies on workplace exposures to mineral oil-based cutting fluids have shown that technicians in machining industries are at risk of contracting allergenic conditions and diseases. Skin and airborne exposures to cutting fluids have been linked with health issues such as 
inflammation of the skin, lungs, eyes, nose, and throat. Other diseases such as dermatitis, obesity, asthma, hypersensitivity pneumonia, upper respiratory tract inflammation, and many cancers have been connected to exposures to mineral oil-based cutting fluids [3]. In particular, the major problem of mineral oil-based cutting fluids is their inadequate handling, which results in pollution of surface and groundwater as a consequence of farm products and food toxicity [4]. Scientists and tribologists are currently investigating various substitutes to mineral oilbased cutting fluids to overcome these challenges. These substitutes include the use of organic lubricants, solid lubricants, and vegetable lubricating oils. Growing demand for renewable resources has paved the way for vegetable oils to substitute for petroleum-based polymeric materials, especially in manufacturing processes [5]. Cutting fluids based on vegetable oil have been used effectively in a variety of machining processes. They often give very appropriate efficiency as lubricants.

Ozcelik et al. [6] evaluated the performances of six cutting fluids, four different VBCFs from sunflower and canola oils with different ratios of extreme pressure additives (SCF I- 8\% EP additives, SCF II - 12\% EP additives, CCF I - 8\% EP additives and CCF II - 12\% EP additive), and two commercial types of CFs (semi-synthetic and mineral) using AISI 304L workpiece and revealed that the overall performance during CCF II (8\% additive) was found to be superior in terms of surface finish, tool wear and cutting forces. Margheritini et al. [7] investigated the turning of mild steel with HSS cutting tool using Neem and Karajan oil-based cutting fluids and reported that surface finish is better using the VBCFs with increasing rate of feed or depth of cut variation as compared to dry and flood cooling conditions. Also, Ikumapayi et al. [8] utilized Taguchi design of experiment technique to study the performance of cutting fluids (servo cut oil, soybean oil, and cottonseed oil) and cutting parameters on surface finish and metal removal rate (MRR) in turning of AISI D2 steel with PVD (TiAIN) coated carbide insert under wet condition and recommended that cottonseed oil and soya bean oil should replace servo cut oil due to their availability, cost, and user-friendly ability while Krishna et al. [9] formulated cutting fluid using coconut oil and observed better performance of nanoboric acid suspension in SAE - 40 and coconut oil during turning operation with a cemented carbide tool. In addition, Ojolo and Ohunakin [10] investigated the effect of machining parameters (depth of cut, feed rate, spindle speed as well as rake angle) on cutting force during cylindrical turning of mild steel, aluminum rod as well as brass using HSS cutting tool under dry and flooded palm kernel oil coolant conditions. The results revealed that dry conditions achieved higher values of cutting forces compared to using wet cutting conditions using palm kernel oilbased coolant. Also, Onuoha et al. [11] investigated the effects of new formulations of vegetable oils developed from groundnut, false walnut oils, and a commercial mineral-based cutting fluid on surface finish during turning of annealed AISI 1330 alloy steel with HSS tool. It was discovered that when groundnut oil-based cutting fluid was used, the optimum parameters for better surface finishing of the workpiece material were obtained.

Over 80 percent of the vegetable oils used as cutting fluids in literature are edible oils (consumable oils). Reported in Table 1 are a few edible and non-edible oils. The overall performances of the investigated edible vegetable oils were good; however, these consumable oils will compete with food-grade and other industrial oils in the future if promoted thereby, making them more expensive as bio-lubricants. This shortcoming creates a gap for further research on less well-known vegetable oils as machining cutting fluids. As a result, a lesserknown vegetable oil-based cutting fluid (watermelon oil) was produced through the process of extraction, characterization as well as formulation and performance in terms of surface finish, 
machine vibration rates, machine sound level, chip morphology, and cutting temperature of the formulated cutting fluid was contrasted with mineral oil-based cutting fluid during turning of AISI 1525 steel under flood cooling application condition. Moreover, Grey Relational Analysis (GRA) was used to investigate the multi-response performance of the two cutting fluids.

Table 1. Summary of earlier findings on the use of vegetable oils as cutting fluids

\begin{tabular}{|c|c|c|c|}
\hline $\mathbf{S} / \mathbf{N}$ & Vegetable oil & Category & Author(s) and year published \\
\hline 1 & Palm & Edible & $\begin{array}{l}\text { Revankar et al. [1], Rahim and Sasahar [12], Nurul et al. [13], Fairuz et al. } \\
\text { [14], Virdi et al. [15], Faheem et al. [16]. }\end{array}$ \\
\hline 2 & Rapeseed & Edible & $\begin{array}{l}\text { Rohit et al. [17], Singh et al. [18], Syed et al. [19], Sabahudin et al. [20], } \\
\text { Ekinovic [21], Itoigawa et al. [22], Deiab et al. [23], Belluco and De Chiffre } \\
\text { [24]. }\end{array}$ \\
\hline 3 & Sunflower & Edible & $\begin{array}{l}\text { Singh } \text { et al. [18], Ozcelik et al. [6], Ozcelik } \text { et al. [25], Ozcelik et al. [26], } \\
\text { Ansari and Kotiveecrachary [27], Fernando et al. [28], Kuram et al. [29], } \\
\text { Shukla } \text { et al. [30], Siti et al. [31], Faheem } \text { et al. [16]. }\end{array}$ \\
\hline 4 & Soybean & Edible & Kumar et al. [32], Ikumapayi et al. [8], Papiya et al. [33] \\
\hline 5 & Canola & Edible & Kuram et al. [29], Ozcelik et al. [6], Ozcelik et al. [25], Ozcelik et al. [26]. \\
\hline 6 & Neem & Non-edible & Marghritini et al. [7], Papiya et al. [33], Susmitha et al. [34] \\
\hline 7 & Karanja & Non-edible & Susmitha et al. [34] \\
\hline 8 & Cottonseed & Edible & Ikumapayi et al. [8], Lawal et al. [35], Sachin et al. [36] \\
\hline 9 & Coconut & Edible & $\begin{array}{l}\text { Ojolo et al. [37], Majak et al. [38], Chinchanikar et al. [39], Kumar et al. } \\
\text { [40], Satheesh et al. [41], Nurul et al. [13], Fairuz et al. [14]. }\end{array}$ \\
\hline 10 & Pongam & Non-edible & Shashidhara and Jayaram $[42,43]$ \\
\hline 11 & Jatropha & Non-edible & Shashidhara and Jayaram $[42,43]$ \\
\hline 12 & Palm Kernel & Edible & Ojolo and Ohunakin [10], Ojolo et al. [37], Lawal et al. [35]. \\
\hline 13 & Groundnut & Edible & Ojolo et al. [37], Papiya et al. [33]. \\
\hline 14 & ShearButter & Edible & Ojolo et al. [37] \\
\hline \multirow[t]{2}{*}{15} & Mustard & Edible & Kivak et al. [3] \\
\hline & Falsenut & Non-edible & Onuoha et al. $[11]$ \\
\hline 16 & Castor & Edible & Kuram et al. [29], Alves and Oliveira [44] \\
\hline 17 & Sesame & Edible & Satheesh et al. [41], Nurul et al. [13], Fairuz et al. [14] \\
\hline 18 & Olive & Edible & Nurul et al. [13], Fairuz et al. [14], Alves and Oliveira [44] \\
\hline 19 & Melon seed & Edible & Mayurkumar et al. [45] \\
\hline
\end{tabular}

\section{Materials and Methods}

2.1. Materials used in the development and production of cutting fluids.

The materials used to formulate the cutting fluid in this study include watermelon oil (Cirtullus lanatus) and other additives such as emulsifier (washing soap), corrosion inhibitor (sodium molybdate), biocide (trizaine), and anti-form agent (silicones).

\subsubsection{Extraction of seeds oil.}

The extraction of seed oils by chemical means was carried out in compliance with the AOAC standard [46]. Using 5 liters of the round bottom flask, soxhlet apparatus, and analytical grade $n$-hexane with a boiling range within $40-60^{\circ} \mathrm{C}$, crude oil products were collected. The oils extracted were analyzed, the yield was measured and properly preserved for further testing at room temperature.

\subsubsection{Characterization of crude oil extract.}

Crude oil extracts were characterized to recognize the properties of watermelon oil related to phytochemistry, physicochemical, and lubricity. This was required in order to 
establish feasible parameters for the composition of cutting fluid. Several tests were conducted on the extracted sample.

(a) Physiochemical characterization of crude oils extract.

Physiochemical tests such as oil $\mathrm{pH}$ (using $\mathrm{pH}$ meter), relative density (using equation 1 according to ASTM D1298-12b method), oil yield (with equation 2), kinematic viscosity (using equation 3), specific gravity (using equation 4 in ASTM D287), refractive index (capillary tube interferometer), acid value (using equation 5 in AOAC [46] standard). Congealing temperature, presence at room temperature, and oil color and odor (as per normal spectrophotometer AOCS Cc 13c -50 methods).

(b) Phytochemical characterization of crude oil extract.

Phytochemical experiments include: Phytochemical studies include Fourier Transform Infra-Red Analysis (FTIR), Gas Chromatography, and Mass Spectra (GCMS). FTIR was obtained using a $4000-400 \mathrm{~cm}^{-1}$ FTIR Perkin Elmer Spectrum. The resolution was eight and two scans. The extracted watermelon sample was spread over the KBR cells, inserted into the cell holder, and placed in the FTIR spectrophotometer. Using a coupled 7890A Agilent Technology GC system, GCMS analysis of crude oil extracts was separated into their chemical constitutions.

(c) Lubricity properties of crude oil extracts.

Pour point was investigated in accordance with ASTM D97, and the cloud point was determined using ASTM D2500. At the same time, both the fire point as well as the flashpoint were conducted based on ASTM D92. Flashpoint was characterized using Cusson Technology Manchester M71RH UK electrically heated Pensky Martens Equipment, and Stanhope Seta Cloud was used to experiment cloud point, while KT16 8AP equipment was employed for the analysis of pour point. The aforementioned equipment is considered for lubricity-related properties conducted on the watermelon crude oil extract.

$$
\rho=\frac{m}{V}
$$

where mass in $\mathrm{kg}, \rho=$ density, and also $\mathrm{V}=$ volume in $\mathrm{cm}^{3}$

$$
\text { Yield } \%=\frac{W_{o}}{W_{p s}} X 100
$$

where $W_{p s}=$ powder sample weight and $W_{o}=$ extracted oil weight

$$
\eta=A d t-\frac{B d}{t}
$$

where $\eta=$ viscosity in centipoises $(\mathrm{cP}), \mathrm{d}=$ density in $\mathrm{g} / \mathrm{ml}, \mathrm{t}=$ time in seconds, $A$ and $B$ are constants

$$
\text { Specific gravity }=\frac{W_{o}}{W_{v w}}
$$

where $W_{o}=$ extracted oil weight, $W_{v w}=$ weight equal to the volume of water 


$$
\text { Acid value }=\frac{56.1 M V}{W}
$$

\subsubsection{Formulation of emulsion cutting fluids.}

As an emulsion metal cutting fluid, the cutting fluid composition was applied. Watermelon oil, blending additives, as well as distilled water were used to produce the emulsion cutting fluids. From factorial preparation guidance, the production of cutting fluids was planned, whereby the influence of four variables was assessed at two rates $\left(2^{4}\right.$ full factorial planning). With 16 solutions derived from full factorial techniques, the cutting emulsion of fluids with 20 percent oil at volumetric water concentrations was prepared differently and in accordance with the standard reported in [47]. The variables (additives) and levels used respectively in the factorial design and experimental matrix of the 24 complete factorial designs are shown in Tables 2 and 3. A quantity exceeding $100 \mathrm{ml}$ was found in each test. A homogeneous mixture was collected at a room temperature of $25^{\circ} \mathrm{C}$ with the aid of a mechanical stirrer at $760 \mathrm{rpm}$ for 10 minutes. However, the mineral-based cutting fluid composition required combining the soluble oil (concentrate) with water in a proportion of 1:9. The preliminary preparation process of watermelon emulsion cutting fluids before blending is shown in Figure 1.

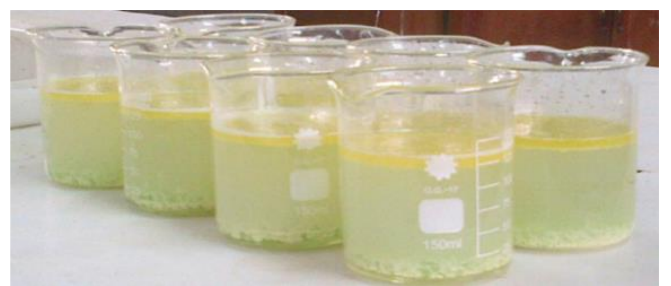

Figure 1: Preliminary preparation of watermelon emulsion cutting fluids.

Table 2. The parameters and levels investigated in the planning of factorial.

\begin{tabular}{l|c|c|c}
\multirow{2}{*}{\multicolumn{1}{c}{ Parameters }} & Symbol & Lower (\%) & Higher (\%) \\
\cline { 3 - 4 } & S1 & 8.0 & 12.0 \\
\hline Emulsifier & S2 & 1.0 & 2.0 \\
\hline Anti-corrosion agent & S3 & 0.5 & 1.0 \\
\hline Anti-microbial agent & S4 & 0.5 & 1.0
\end{tabular}

Table 3. Volume of cutting fluid for initial preparations

\begin{tabular}{l|c|l|l|l|c|c|c}
$\begin{array}{l}\text { Assay } \\
\text { No. }\end{array}$ & $\mathbf{S 1}(\mathbf{m L})$ & $\begin{array}{c}\mathbf{S 2} \\
(\mathbf{m L})\end{array}$ & $\begin{array}{l}\mathbf{S 3} \\
(\mathbf{m L})\end{array}$ & $\begin{array}{l}\mathbf{S 4} \\
(\mathbf{m L})\end{array}$ & $\begin{array}{c}\text { Amount of oil } \\
\text { in the } \\
\text { container } \\
(m L)\end{array}$ & $\begin{array}{c}\text { Amount of } \\
\text { water in the } \\
\text { container } \\
(m L)\end{array}$ & $\begin{array}{c}\text { The total amount } \\
\text { of fluid in a } \\
\text { container }(m L)\end{array}$ \\
\hline 1 & 8.0 & 1.0 & 0.5 & 0.5 & 20 & 70 & 100 \\
\hline 2 & 12.0 & 1.0 & 0.5 & 0.5 & 20 & 66 & 100 \\
\hline 3 & 8.0 & 2.0 & 0.5 & 0.5 & 20 & 69 & 100 \\
\hline 4 & 12.0 & 2.0 & 0.5 & 0.5 & 20 & 65 & 100 \\
\hline 5 & 8.0 & 1.0 & 1.0 & 0.5 & 20 & 69.5 & 100 \\
\hline 6 & 12.0 & 1.0 & 1.0 & 0.5 & 20 & 65.5 & 100 \\
\hline 7 & 8.0 & 2.0 & 1.0 & 0.5 & 20 & 68.5 & 100 \\
\hline 8 & 12.0 & 2.0 & 1.0 & 0.5 & 20 & 64.5 & 100 \\
\hline 9 & 8.0 & 1.0 & 0.5 & 1.0 & 20 & 69.5 & 100 \\
\hline 10 & 12.0 & 1.0 & 0.5 & 1.0 & 20 & 65.5 & 100 \\
\hline 11 & 8.0 & 2.0 & 0.5 & 1.0 & 20 & 68.5 & 100 \\
\hline 12 & 12.0 & 2.0 & 0.5 & 1.0 & 20 & 64.5 & 100 \\
\hline 13 & 8.0 & 1.0 & 1.0 & 1.0 & 20 & 69 & 100 \\
\hline 14 & 12.0 & 1.0 & 1.0 & 1.0 & 20 & 65 & 100 \\
\hline 15 & 8.0 & 2.0 & 1.0 & 1.0 & 20 & 68 & \\
\hline 16 & 12.0 & 2.0 & 1.0 & 1.0 & 20 & 64 & 100 \\
\hline
\end{tabular}




\subsubsection{Characterization of developed cutting fluid.}

Formulated mixtures of the watermelon emulsion cutting fluids in Table 3 were characterized using $\mathrm{pH}$. The $\mathrm{pH}$ value is estimated using a digital $\mathrm{pH}$ meter. The $\mathrm{pH}$ values' results were statistically analyzed using the MINITAB 16 experimental design software. The software used for the analysis uses a polynomial second degree, predicted by equation 6 , to estimate the parameters $\mathrm{Y}$, which includes all factors and perhaps the most effective way of interacting with the factors [47].

$$
Y=\beta_{o}+\sum \beta_{i} X_{i}+\sum \beta_{i i} X_{i}^{2}+\sum \beta_{i j} X_{i} X_{j}
$$

where $\beta_{\circ}$ is constant, $\beta_{i}$ and $\beta_{i j}$ are coefficient of $i j, X i$ representing independent variables, and $X_{i j}$ shows their relations [48]. The optimum values obtained in this research were used to produce the final metal cutting fluid that was used for machining.

\subsection{Methodology for machining techniques and materials used.}

\subsubsection{Experiemntal design.}

The experimental setup was focused on Taguchi $\mathrm{L}_{9}$ design. For the experiment, three cutting scenarios were selected, namely: depth of cut, spindle speed, as well as feed rate. Consequently, three input variables exist, and each variable has assumed three levels, as revealed in Table 4. Taguchi established the $\mathrm{L}_{9}\left(3^{3}\right)$ orthogonal array frameworks for a threefactor-three-level experiment. Therefore, in conjunction with the Taguchi $\mathrm{L}_{9}$ orthogonal array of research setup, a total of nine machining trials were employed. As presented in Table 5, each cutting fluid assessment was carried out on a different, fresh cutting edge and workpiece material.

Table 4. Various levels of machining variables s used.

\begin{tabular}{c|c|c|c} 
Factor & Level 3 & Level 2 & Level 1 \\
\hline Feed rate $(\mathrm{mm} / \mathrm{rev})$ & 0.20 & 0.15 & 0.1 \\
\hline Spindle speed $(\mathrm{m} / \mathrm{min})$ & 710 & 500 & 355 \\
\hline Depth of cut $(\mathrm{mm})$ & 1.25 & 1.00 & 0.75
\end{tabular}

Table 5. $\mathrm{L}_{9}\left(3^{3}\right)$ Standard for orthogonal array machining method.

\begin{tabular}{l|c|c|c} 
Trial No. & Feed rate $(\mathbf{m m} / \mathbf{r e v})$ & Spindle speed (m/min) & Depth of cut (mm) \\
\hline 1 & 0.1 & 355 & 0.75 \\
\hline 2 & 0.15 & 355 & 1.00 \\
\hline 3 & 0.20 & 355 & 1.25 \\
\hline 4 & 0.1 & 500 & 1.00 \\
\hline 5 & 0.15 & 500 & 1.25 \\
\hline 6 & 0.20 & 500 & 0.75 \\
\hline 7 & 0.1 & 710 & 1.25 \\
\hline 8 & 0.15 & 710 & 0.75 \\
\hline 9 & 0.20 & 710 & 1.00
\end{tabular}

\subsubsection{Turning Operation.}

The turning operation was carried out with a three-jaw AJAX Lathe Machine (Model No. 20186; 5hp rated power and variable spindle: 16-2000 rpm). For the cutting process, a tungsten carbide insert was used (model of tool holder: MCLNR-2020K12, model of insert: CNMG-12040408, size of insert: 12, length of shank: $100 \mathrm{~mm}$, and thickness of insert: 4,7624 $\mathrm{mm}$ ). The following investigations were carried out on AISI 1525 round steel bars, such as chip formation, surface roughness, cutting temperature, machine sound level, and machine 
vibration. The shaft was originally $1500 \mathrm{~mm}$ long and $80 \mathrm{~mm}$ in diameter, then reduced to 320 $\mathrm{mm}$ in length and $80 \mathrm{~mm}$ in diameter, ensuring firmness and preventing bending during the turning process. To facilitate better clamping force during turning, each test sample was placed on the lathe between the chuck and the living core [48]. Before the beginning of the experiment, each specimen's thin exterior surface was machined away. As indicated in Table 4, the workpiece was machined at various feed rates, depth of cut, as well as the spindle speed.

\subsubsection{Assessment of Surface Integrity.}

The surface integrity of the machined components of the workpiece was assessed using a portable surface roughness tester (SRT-6200). For each sample, three measurements were taken along the shaft axis, and the approximate value was determined and recorded.

\subsubsection{Evaluation of Cutting temperature.}

The cutting temperature was determined using a PeakTech Infrared thermometer and a standard emissivity value of 0.95 . Values were recorded during machining by pointing the thermometer's probe to the chip-tool interface, which gave the interface the degree of hotness. The thermometer was physically held away from the chip tool interface at $5 \mathrm{~cm}$. For every sample, three different measurement points were considered to ensure reproducibility and consistency, and the average value was reported.

\subsubsection{Machine vibration measurement.}

The vibrations from the device were measured using a vibration meter for various cutting parameters (Lutron Vibration Meter VB8206SD was used). The vibration meter probe was positioned very close to the spindle beside the headstock of the unit. The meter gives its reading in terms of displacement, velocity, and acceleration, but the reading for this study was taken in terms of acceleration $\left(\mathrm{m} / \mathrm{s}^{2}\right)$. The device has the capacity (inform of the sensor) to record the minimum and maximum spindle vibration over time.

\subsubsection{Machine sound level measurement.}

The sound level meter Testo815, which uses a sound recording and analysis software program called cool edit, was used to assess noise from the system for various cutting parameters. The software application was opened, and a sample rate of 96000, stereo channels, and a 32-bit float resolution of the noise recording interface was configured. The laptop was situated about $1.2 \mathrm{~m}$ away from the device.

\section{Results and Discussion}

\subsection{Physiochemical test.}

Table 6 displays the effects of vegetable oil in terms of physicochemical properties. The color of the processed watermelon oil is pale yellow, while the state of the extracts of the oil, as shown in Figure 2, is liquid at room temperature. The oil content of each seed in watermelon seeds was found to be $54 \%$ by weight, which may promote its use for machining tests and make it cost-effective for the mass production of lubricants in Nigeria. In addition, the specific gravity of the concentrate of watermelon oil is 0.893 , falling within the range of specific gravities recorded for some identified tropical seeds for similar vegetable oil extracts 
[49]. There is a $\mathrm{pH}$ of 8.1 in the extracted oil that comes within an alkaline state. This is in accordance with the previous study by Lawal et al. [35] and Pal et al. [58], which indicated that $\mathrm{pH}$ values below 7.0 during machining processes might appear to corrode metal. In addition, the analysis of the refractive index reveals that the extracts of watermelon oil did not fulfill ASTM values ranging from 1.476 to 1.479 (ASTM International, 2002). This could be due to the presence of additional particles and other constituents of the crude oil blend, such as the extraction solvent. On the other hand, the refractive index value was comparable to that reported by Eze [49], who employed pumpkin seed oil. The acid value shows fatty acid content and is usually symptomatic of deterioration due to enzymatic activity; the maximum allowable level is $4 \mathrm{mg}$ potassium hydroxide oil (CODEX Alimentarius Board, 1982). The findings of this study indicate that the acid value of watermelon oil is 3.24 , which is within the desired level, according to the literature. The high acidity level is attributable to the free fatty acids present in the oil, which can be adjusted through processing, improving the oil's production quality [50]. Viscosity also reflects a measure of fluid resistance to shear stress deformation. In general, it is known to be thick or resistant to pouring. As the temperature rises from 40 to $80^{\circ} \mathrm{C}$, the viscosity of watermelon oil decreases by 2.0 times. The congealing temperature was also measured, with a value of $2{ }^{\circ} \mathrm{C}$; the extracted watermelon oil had a very low concentration. Watermelon oil has a low congealing temperature, which implies it may be used at low temperatures.

Table 6. Physicochemical properties of the watermelon oil extracts.

\begin{tabular}{|c|c|}
\hline Measured Parameter & Value \\
\hline Colour & Pale yellow \\
\hline Appearance at room temperature & Liquid form \\
\hline Odor & Pleasant odor \\
\hline Acid value $(\mathrm{mg} \mathrm{KOH} / \mathrm{g})$ & 3.24 \\
\hline$\%$ oil yield & $54 \%$ \\
\hline Kinematic viscosity $(\mathrm{cP})$ at $80^{\circ} \mathrm{C}$ & 19.8 \\
\hline Kinematic viscosity $(\mathrm{cP})$ at $40^{\circ} \mathrm{C}$ & 39.6 \\
\hline Specific gravity & 0.893 \\
\hline Relative density $\left(\mathrm{g} / \mathrm{cm}^{3}\right)$ & 0.919 \\
\hline Refractive index at $20^{\circ} \mathrm{C}$ & 1.4630 \\
\hline Congealing temperature $\left({ }^{\circ} \mathrm{C}\right)$ & 2.0 \\
\hline $\mathrm{pH}$ & 8.1 \\
\hline \multicolumn{2}{|c|}{ 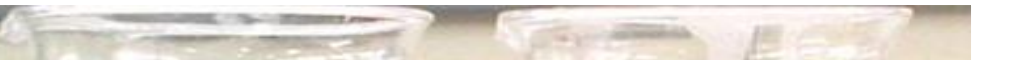 } \\
\hline-800 & \\
\hline-600 & \\
\hline $1000 \mathrm{mi}$ & \\
\hline-200 & \\
\hline
\end{tabular}

Figure 2. Extracted watermelon oil at room temperature.

\subsection{Phytochemical characterization of crude oil extracts.}

\subsubsection{Fourier Transform Infra-Red.}

The FT-IR spectra were used to categorize the structural features and bands in the crude oils corresponding to various stretching and bending vibrations in the mid-infrared region. The FT-IR outcome range of the oil sample in terms of the spectrum is as displayed in Table 7. 
Table 7. Spectrum of FT-IR of the oil sample.

\section{\begin{tabular}{l|l} 
Oil sample & FT-IR Results $/ \mathbf{c m}^{-1}$
\end{tabular}}

\begin{tabular}{l|l|l} 
Watermelon & $3009.3-2854.6$ & $1744.7,1712.2,1242$
\end{tabular}

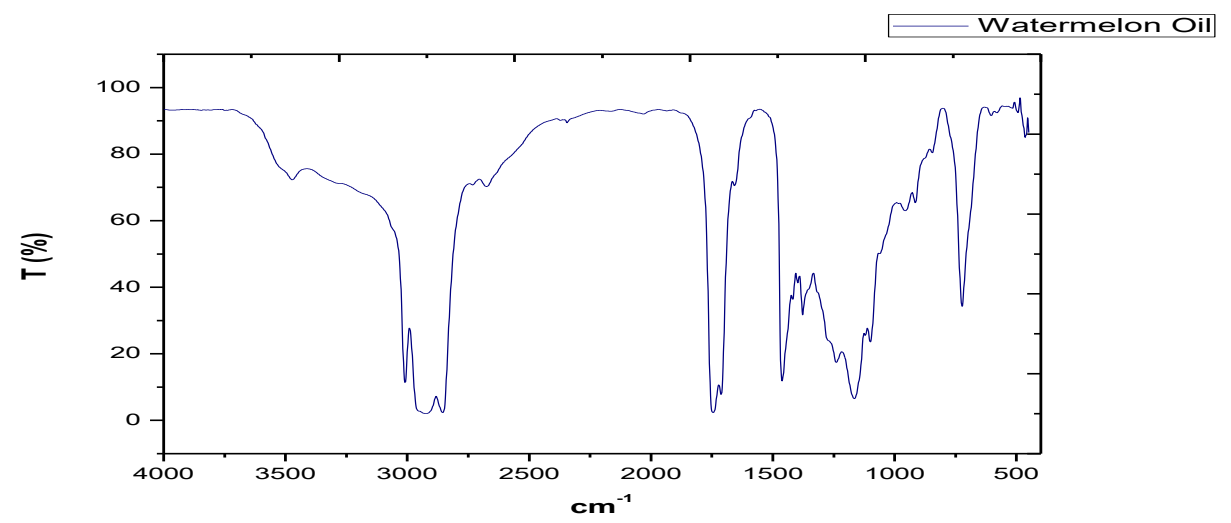

Figure 3. FTIR for crude watermelon oil.

The study of the FT-IR in Figure 3 reveals the essential functional moieties connected with the clarification of oils are confirmed. Asymmetry stretching vibration of $1745 \mathrm{~cm}^{-1}$ was shown to be indicative of an ester's carbonyl moiety in the investigation. The occurrence in the fingerprint area of both symmetry and asymmetry stretching vibrations in the range 3009.3$2854.6 \mathrm{~cm}^{-1}$ and their respective bending vibrations identifies the existence of carbon atoms with p-orbital characteristics of 75 percent and 66.6 percent. In watermelon oil, the stretching vibration of around $1657 \mathrm{~cm}^{-1}$ suggests a carbon atom with a signature of $\mathrm{sp}^{2}$.

\subsubsection{Gas chromatography.}

The chromatogram obtained from the gas chromatography-mass spectra analysis carried out on the oil sample is presented in Table 8 .

Table 8. An analysis of gas chromatography of watermelon- isolated phyto-compounds.

\begin{tabular}{|c|c|c|c|c|c|}
\hline $\begin{array}{c}\text { Chromatography } \\
\text { peak }\end{array}$ & $\begin{array}{c}\begin{array}{c}\text { Compound } \\
\text { nomenclature }\end{array} \\
\end{array}$ & $\begin{array}{c}\text { Molecular } \\
\text { formula }\end{array}$ & $\begin{array}{c}\text { Percentage } \\
\text { content }\end{array}$ & $\begin{array}{l}\text { Retention } \\
\text { time (min) }\end{array}$ & $\begin{array}{c}\text { Molecular } \\
\text { weight }\end{array}$ \\
\hline \multirow{4}{*}{$\begin{array}{l}1 \\
2 \\
3 \\
4\end{array}$} & \multirow{4}{*}{$\begin{array}{c}\text { n-hexadecanoic acid } \\
9,12 \text { - octadecadienoic } \\
\text { acid } \\
1 \mathrm{H} \text { - indole } \\
\text { Cyclopropane }\end{array}$} & $\mathrm{C}_{16} \mathrm{H}_{32} \mathrm{O}_{2}$ & 57.87 & 18.247 & 256 \\
\hline & & $\mathrm{C}_{18} \mathrm{H}_{32} \mathrm{O}_{2}$ & 27.49 & 19.747 & 280 \\
\hline & & $\mathrm{C}_{8} \mathrm{H}_{7} \mathrm{~N}$ & 3.73 & 22.859 & 117 \\
\hline & & $\mathrm{C}_{3} \mathrm{H}_{6}$ & 11.36 & 25.783 & 42 \\
\hline
\end{tabular}

Results obtained from the GCMS performed on the oil sample showed the traces of 4 phyto-compounds in watermelon oil. The extracted oil is a bio-based formulation whose complementary penetrating ability with a safe and environmentally degrading history may better replace mineral-based lubricants. The findings also showed that the most prevalent bioactive compound in watermelon is hexadecanoic acid. Hexadecanoic acid is widely used in cosmetics, soap, as well as releases substances. Hexadecanoic acid has not been documented in the implementation of cutting fluids, but research can be carried out because of its application in skin products, i.e., hexadecanoic acid is friendly to humans. 9, 12-octadecadienoic acid (also known as linoleic acid), the beauty products industry is becoming increasingly prominent due to its beneficial properties on the skin. Research revealed that linoleic acid's anti-inflammatory, acne-reducing, and moisture-retentive efficacy when administered topically to the skin [5153]. In watermelon oil, linoleic acid can help eliminate skin cancer problems and respiratory problems, particularly acne-related, through the use of mineral-based cutting fluids. The oil 
sample from watermelon contains $27.49 \%$ of 9, 12-octadecanoic acid in its composition, and this makes watermelon oil suitable as an application for cutting fluids. In addition, $1 \mathrm{H}$-Indole, which is solid at room temperature, has a flowery smell at very low concentrations. It is an additive in several flower scents and perfumes (such as orange blossoms). Approximately 2.5 percent of Indole [54] contains natural jasmine oil used in the perfume industry. Most of the cutting fluids developed industrially contain additives such as fragrances, dispersants, corrosion inhibitors, biocides, colorants, etc. 1H-Indole can serve as an effective additive in cutting fluid manufacturing. Likewise, cyclopropane, which is also present in the oil, does not irritate the respiratory organs and therefore does not inhibit breathing [55]. The findings on properties relevant to lubricity are reported in Table 9. Values obtained are within the ASTM norm.

Table 9. Lubricity-based properties of extracts of watermelon oil.

\begin{tabular}{c|c} 
Parameter & Results obtained \\
\hline Fire point & 190 \\
\hline Cloud point & 8 \\
\hline Flash point & 178 \\
\hline Pour point & 5
\end{tabular}

\subsection{Characterization of cutting fluids.}

Based on the validation results obtained, emulsion metal cutting fluids were formulated using watermelon oil as the base oils. After validation, the new emulsion cutting fluid used for machining was formulated and characterized using the optimal values. Optimum values for watermelon emulsion cutting fluid additives collected were anti-corrosion (2.0 vol. \%); emulsifying agent (12.0 vol. \%); antimicrobial agent (1.0 vol. \%); anti-corrosion agent (1.0 vol. $\%)$; as well as (1.0 vol. \%). The mineral oil obtained as distilled oil has been used with no extra additives to prepare emulsion cutting fluid.

Table 10. Characteristics of watermelon and mineral oil-based cutting fluids.

\begin{tabular}{c|c|c} 
Parameter & Watermelon oil & Mineral oil \\
\hline Colour & Yellowish & Milky white \\
\hline Viscosity $(\mathrm{Cst})$ at $25^{\circ} \mathrm{C}$ & 1.6 & 1.0 \\
\hline $\mathrm{pH}$ & 9.7 & 8.5 \\
\hline Density $\left(\mathrm{g} / \mathrm{cm}^{3}\right)$ at $25^{\circ} \mathrm{C}$ & 0.9192 & 0.9205 \\
\hline Stability & Stable & Stable
\end{tabular}

The results shown in Table 10 indicate that the properties of the watermelon oil-based cutting fluid are comparable with the mineral-based cutting fluid since it is stable with a $\mathrm{pH}$ of 9.7 and has a viscosity of $1.6 \mathrm{Cst}$, thereby making it effective and safe to use as a cutting fluid in the machining process.

\subsection{Results obtained from the experiment and the values Signal-to-noise (S/N) ratios}

Tables 10 and 11 display the outcome of the research obtained using the produced watermelon oil as well mineral oil along with their respective signal-to-noise ratio $(S / N)$ values. The $\mathrm{S} / \mathrm{N}$ ratios were determined using equation 7 for individual responses. The obtained measurements reported in Tables 11 and 12 are also shown in Fig. 4.

$$
\frac{S}{N}=-10 \log \frac{1}{n}\left(\sum y_{i}^{2}\right)
$$


where $\mathrm{n}$ is the number of test samples, and $\mathrm{y}$ is the number of responses for a particular factor level combination.

Table 11. Experimental process parameters, results and $\mathrm{S} / \mathrm{N}$ ratios (Watermelon oil-based cutting fluid).

\begin{tabular}{|c|c|c|c|c|c|c|c|c|c|c|c|}
\hline \multirow[t]{2}{*}{$\begin{array}{l}\text { Trial } \\
\text { No. }\end{array}$} & \multicolumn{3}{|c|}{ Cutting parameters } & \multicolumn{2}{|c|}{ Surface finish $(R a)$} & \multicolumn{2}{|c|}{$\begin{array}{l}\text { Cutting } \\
\text { temperature }(T)\end{array}$} & \multicolumn{2}{|c|}{$\begin{array}{l}\text { Machine vibration } \\
(V)\end{array}$} & \multicolumn{2}{|c|}{$\begin{array}{l}\text { Machine sound level } \\
(S)\end{array}$} \\
\hline & $\begin{array}{l}\text { Spindle } \\
\text { speed } \\
\text { (rev/min) }\end{array}$ & $\begin{array}{l}\text { Feed rate } \\
(\mathrm{mm} / \mathrm{rev})\end{array}$ & $\begin{array}{l}\text { Depth } \\
\text { of cut } \\
(\mathrm{mm})\end{array}$ & $\begin{array}{l}\text { Ra } \\
(\mu m)\end{array}$ & $\begin{array}{l}\text { S/N for } \\
\operatorname{Ra}(d B)\end{array}$ & $\begin{array}{l}\text { T }\left(^{\circ}\right. \\
C)\end{array}$ & $\begin{array}{l}\text { S/N for } T \\
(d B)\end{array}$ & $\begin{array}{l}\mathbf{V} \\
\left(\mathrm{m} / \mathrm{s}^{2}\right)\end{array}$ & $\begin{array}{l}\text { S/N for } \\
\text { V }(d B)\end{array}$ & $\mathbf{S}(d B)$ & $\begin{array}{l}\mathrm{S} / \mathrm{N} \text { for } \mathrm{S} \\
(d B)\end{array}$ \\
\hline 1 & 355 & 0.10 & 0.75 & 2.605 & -8.316 & 56.2 & -34.995 & 5.4 & -14.648 & 91.43 & -39.222 \\
\hline 2 & 355 & 0.15 & 1.00 & 3.88 & -11.777 & 50.5 & -34.066 & 14.4 & -23.167 & 101.2 & -40.104 \\
\hline 3 & 355 & 0.20 & 1.25 & 8.47 & -18.558 & 52.7 & -34.436 & 12.7 & -22.076 & 101.6 & -40.138 \\
\hline 4 & 500 & 0.10 & 1.00 & 6.35 & -16.055 & 49.6 & -33.910 & 56.8 & -35.087 & 109.7 & -40.804 \\
\hline 5 & 500 & 0.15 & 1.25 & 8.31 & -18.392 & 65.1 & -36.272 & 27.0 & -28.627 & 111.5 & -40.945 \\
\hline 6 & 500 & 0.20 & 0.75 & 8.93 & -19.017 & 46.5 & -33.349 & 94.6 & -39.518 & 111.7 & -40.961 \\
\hline 7 & 710 & 0.10 & 1.25 & 6.25 & -15.918 & 50.8 & -34.117 & 75.0 & -37.501 & 108.8 & -40.733 \\
\hline 8 & 710 & 0.15 & 0.75 & 7.48 & -17.478 & 68.3 & -36.688 & 65.8 & -36.365 & 109.0 & -40.749 \\
\hline 9 & 710 & 0.20 & 1.00 & 9.34 & -19.407 & 91.9 & -39.266 & 77.1 & -37.741 & 113.5 & -41.100 \\
\hline
\end{tabular}

Table 12. Experimental process parameters, results and $S / N$ ratios (Mineral oil-based cutting fluid).

\begin{tabular}{|c|c|c|c|c|c|c|c|c|c|c|c|}
\hline \multirow[t]{2}{*}{$\begin{array}{l}\text { Trial } \\
\text { No. }\end{array}$} & \multicolumn{3}{|c|}{ Cutting parameters } & \multicolumn{2}{|c|}{ Surface finish $(R a)$} & \multicolumn{2}{|c|}{$\begin{array}{l}\text { Cutting } \\
\text { temperature }(T)\end{array}$} & \multicolumn{2}{|c|}{$\begin{array}{l}\text { Machine vibration } \\
(V)\end{array}$} & \multicolumn{2}{|c|}{$\begin{array}{l}\text { Machine sound level } \\
(S)\end{array}$} \\
\hline & $\begin{array}{l}\text { Spindle } \\
\text { speed } \\
\text { (rev/min) }\end{array}$ & $\begin{array}{l}\text { Feed rate } \\
(\mathrm{mm} / \mathrm{rev})\end{array}$ & $\begin{array}{l}\text { Depth } \\
\text { of cut } \\
(\mathrm{mm})\end{array}$ & $\begin{array}{l}\text { Ra } \\
(\mu m)\end{array}$ & $\begin{array}{l}\mathrm{S} / \mathrm{N} \text { for } \\
\operatorname{Ra}(d B)\end{array}$ & $\mathrm{T}\left({ }^{\circ} \mathrm{C}\right)$ & $\begin{array}{l}\text { S/N for } T \\
(d B)\end{array}$ & $\begin{array}{l}\mathrm{V} \\
\left(\mathrm{m} / \mathrm{s}^{2}\right)\end{array}$ & $\begin{array}{l}\mathrm{S} / \mathrm{N} \text { for } \\
\mathrm{V}(d B)\end{array}$ & $S(d B)$ & $\begin{array}{l}\mathrm{S} / \mathrm{N} \text { for } \mathrm{S} \\
(d B)\end{array}$ \\
\hline 1 & 355 & 0.10 & 0.75 & 2.545 & -8.114 & 46.8 & -33.405 & 27.03 & -28.637 & 85.7 & -38.660 \\
\hline 2 & 355 & 0.15 & 1.00 & 3.521 & -10.933 & 57.2 & -35.148 & 7.91 & -17.964 & 85.9 & -38.680 \\
\hline 3 & 355 & 0.20 & 1.25 & 8.47 & -18.558 & 59.8 & -35.534 & 28.7 & -29.158 & 86.0 & -38.690 \\
\hline 4 & 500 & 0.10 & 1.00 & 6.22 & -15.876 & 76.6 & -37.685 & 15.5 & -23.807 & 85.7 & -38.660 \\
\hline 5 & 500 & 0.15 & 1.25 & 7.41 & -17.396 & 60.2 & -35.592 & 42.9 & -32.649 & 95.5 & -39.600 \\
\hline 6 & 500 & 0.20 & 0.75 & 8.83 & -18.919 & 105.5 & -40.465 & 21.4 & -26.608 & 108.8 & -40.733 \\
\hline 7 & 710 & 0.10 & 1.25 & 6.50 & -16.258 & 106.2 & -40.522 & 29.2 & -29.308 & 106.9 & -40.580 \\
\hline 8 & 710 & 0.15 & 0.75 & 7.70 & -17.730 & 109.2 & -40.764 & 12.9 & -22.212 & 111.1 & -40.914 \\
\hline 9 & 710 & 0.20 & 1.00 & 8.80 & -18.890 & 111.8 & -40.969 & 29.95 & -29.528 & 109.0 & -40.749 \\
\hline
\end{tabular}

\subsection{Analysis of variance.}

To examine the substantial influence as well as the percentage impacts of individual machining conditions, experimental findings were evaluated using analysis of variance. This study was performed using a confidence level of $95 \%$ and a significance level of $5 \%$. For the individual responses of watermelon oil-based cutting fluid and mineral oil-based cutting fluid, Tables 13-16 show the Amount of Mean Square (MS), F-value (F), Square (SS), Percentage contribution (P) as well as Degree of Freedom (DOF).

Table 13. ANOVA for surface roughness.

\begin{tabular}{|c|c|c|c|c|c|c|c|c|c|c|}
\hline \multirow{2}{*}{ Factor } & \multicolumn{5}{|c|}{ Watermelon oil } & \multicolumn{5}{|c|}{ Mineral oil } \\
\hline & DOF & SS & MS & $\mathbf{F}$ & $\mathbf{P}$ & DOF & SS & MS & $\mathbf{F}$ & $\mathbf{P}$ \\
\hline Spindle speed & 2.00 & 15.63 & 7.82 & 8.71 & 36.24 & 2.00 & 23.35 & 11.68 & 23.78 & 41.25 \\
\hline Feed rate & 2.00 & 22.55 & 11.28 & 12.57 & 52.28 & 2.00 & 27.99 & 14.00 & 28.50 & 49.44 \\
\hline Depth of cut & 2.00 & 3.16 & 1.58 & 1.76 & 7.32 & 2.00 & 4.29 & 2.14 & 4.37 & 7.57 \\
\hline Error & 2.00 & 1.79 & 0.90 & & 4.16 & 2.00 & 0.98 & 0.49 & & 1.73 \\
\hline Total & 8.00 & 43.13 & 5.39 & & 100.00 & 8.00 & 56.61 & 7.08 & & 100.00 \\
\hline
\end{tabular}

Table 14. ANOVA for cutting temperature.

\begin{tabular}{|c|c|c|c|c|c|c|c|c|c|c|}
\hline \multirow[t]{2}{*}{ Factor } & \multicolumn{5}{|c|}{ Watermelon oil } & \multicolumn{5}{|c|}{ Mineral oil } \\
\hline & DOF & SS & MS & $\mathbf{F}$ & $\mathbf{P}$ & DOF & SS & MS & $\mathbf{F}$ & $\mathbf{P}$ \\
\hline Spindle speed & 2.00 & 771.80 & 385.90 & 5.73 & 47.13 & 2.00 & 6016.00 & 3008.00 & 40.03 & 81.09 \\
\hline Feed rate & 2.00 & 420.80 & 210.40 & 3.13 & 25.69 & 2.00 & 1150.00 & 575.00 & 7.65 & 15.50 \\
\hline Depth of cut & 2.00 & 310.50 & 155.25 & 2.31 & 18.96 & 2.00 & 102.70 & 51.35 & 0.68 & 1.38 \\
\hline Error & 2.00 & 134.60 & 67.30 & & 8.22 & 2.00 & 150.30 & 75.15 & & 2.03 \\
\hline Total & 8.00 & 1637.70 & 204.71 & & 100.00 & 8.00 & 7419.00 & 927.38 & & 100.00 \\
\hline
\end{tabular}


Table 15. ANOVA for machine vibration.

\begin{tabular}{|c|c|c|c|c|c|c|c|c|c|c|}
\hline \multirow[t]{2}{*}{ Factor } & \multicolumn{5}{|c|}{ Watermelon oil } & \multicolumn{5}{|c|}{ Mineral oil } \\
\hline & DOF & SS & MS & $\mathbf{F}$ & $\mathbf{P}$ & DOF & SS & MS & $\mathbf{F}$ & $\mathbf{P}$ \\
\hline Spindle speed & 2.00 & 6358.00 & 3179.00 & 6.67 & 72.49 & 2.00 & 1530.50 & 765.25 & 3.33 & 27.09 \\
\hline Feed rate & 2.00 & 1010.00 & 505.00 & 1.06 & 11.52 & 2.00 & 1830.50 & 915.25 & 3.99 & 32.40 \\
\hline Depth of cut & 2.00 & 449.60 & 224.80 & 0.47 & 5.13 & 2.00 & 1829.80 & 914.90 & 3.98 & 32.39 \\
\hline Error & 2.00 & 953.40 & 476.70 & & 10.87 & 2.00 & 459.20 & 229.60 & & 8.13 \\
\hline Total & 8.00 & 8771.00 & 1096.38 & & 100.00 & 8.00 & 5650.00 & 706.25 & & 100.00 \\
\hline
\end{tabular}

Table 16. ANOVA for machine sound level.

\begin{tabular}{|c|c|c|c|c|c|c|c|c|c|c|}
\hline \multirow[t]{2}{*}{ Factor } & \multicolumn{5}{|c|}{ Watermelon oil } & \multicolumn{5}{|c|}{ Mineral oil } \\
\hline & DOF & SS & MS & $\mathbf{F}$ & $\mathbf{P}$ & DOF & SS & MS & $\mathbf{F}$ & $\mathbf{P}$ \\
\hline Spindle speed & 2.00 & 319.12 & 159.56 & 64.21 & 79.38 & 2.00 & 803.90 & 401.95 & 13.44 & 74.33 \\
\hline Feed rate & 2.00 & 49.90 & 24.95 & 10.04 & 12.41 & 2.00 & 108.80 & 54.40 & 1.82 & 10.06 \\
\hline Depth of cut & 2.00 & 28.03 & 14.02 & 5.64 & 6.97 & 2.00 & 109.10 & 54.55 & 1.82 & 10.09 \\
\hline Error & 2.00 & 4.97 & 2.49 & & 1.24 & 2.00 & 59.80 & 29.90 & & 5.53 \\
\hline Total & 8.00 & 402.02 & 50.25 & & 100.00 & 8.00 & 1081.60 & 135.20 & & 100.00 \\
\hline
\end{tabular}

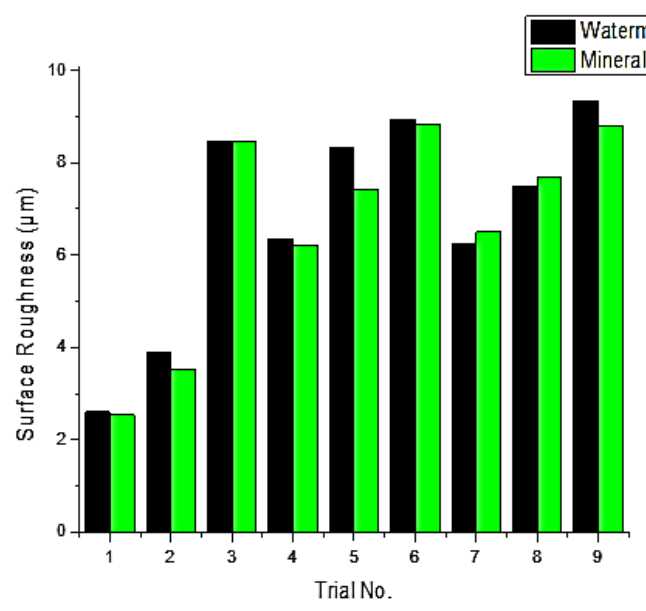

(a)

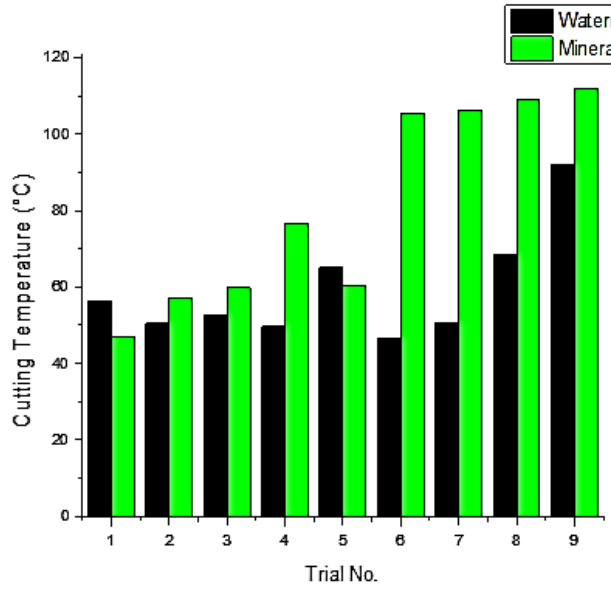

(b)

Figure 4. (a) Effect of emulsion cutting fluids on surface roughness; (b) Effect of emulsion cutting fluids on cutting temperature; (c) Effect of emulsion cutting fluids on machine vibrations; (d) Effect of emulsion cutting fluids on machine sound level.

The ANOVA results presented in Table 13 revealed that the performance (surface roughness) of the two oils is mostly influenced by feed rate [watermelon oil (52.28\%); mineral oil $(49.44 \%)$ ]. This is followed by spindle speed [watermelon oil $(36.24 \%)$; mineral oil $(41.25 \%)$ ], and the least significant factor is the depth of cut [watermelon oil (7.32\%); mineral oil (7.57\%)]. Similarly, the ANOVA results for cutting temperature (Table 14) indicate that spindle speed has the most significant impact on the performance of the watermelon oil $(88.78 \%)$ and mineral oil $(81.09 \%)$, followed by feed rate [watermelon oil (25.69\%); mineral oil (15.5\%)], while the depth of cut posed the least significant effect [watermelon oil (18.96\%) and depth of cut for mineral oil (1.38\%). Also, the vibration of the machine (Table 15) is most affected by spindle speed for watermelon oil (72.49\%) and feed rate $(32.40 \%)$. This is followed by feed rate $(11.52 \%)$ for watermelon oil and depth of cut (32.39) for mineral oil. Finally, the noise level of the machine (see Table 16) is most influenced by spindle speed [watermelon oil (79.38\%); mineral oil (74.33), followed by feed rate for watermelon oil (12.41\%) as well as the depth of cut for mineral oil (10.09)] and the least significant factor is the depth of cut for watermelon oil (6.97\%) and feed rate for mineral oil (10.06\%). Since their p-values are higher than 0.05 , the influences of all the variables are important. 
3.6. Empirical model equations.

Model equations shown in equations 8-15 were obtained using MINITAB 17 statistical software. These models consist of cutting elements like Feed Rate (FR), Spindle speed (SS) as well as Depth of Cut (DOC). The model approach was used to dictate the responses (surface finish, cutting temperature, machine vibration, and noise level). Optimized values obtained from GRA will be used to conduct experiments and validate the regression equations for responses.

\section{For WBCF}

Surface Roughness $(\mu \mathrm{m})=-5.26+0.00702 \mathrm{SS}+38.5 \mathrm{FR}+2.68$ DOC

$R_{s q}=79.47 \%$ and $R_{s q(a d j)}=67.15 \%$

Cutting Temperature $\left({ }^{\circ} \mathrm{C}\right)=17.0+0.0506 S S+115 F R-1.6$ DOC

$R_{s q}=72.10 \%$ and $R_{s q(a d j)}=57.36 \%$

Machine Vibration $\left(m / s^{2}\right)=-28.6+0.1661 S S+157 F R-34.1$ DOC

$R_{s q}=69.34 \%$ and $R_{s q(a d j)}=50.95 \%$

Machine Sound Levd $(\mathrm{dB})=74.8+0.0321 \mathrm{SS}+56.2 \mathrm{FR}-6.51 \mathrm{DOC}$

$\mathrm{R}_{\mathrm{sq}}=64.87 \%$ and $\mathrm{R}_{\mathrm{sq}(\mathrm{adj})}=53.80 \%$

For $M B C F$

Surface Roughness $(\mu \mathrm{m})=-4.84+0.00744 S S+3.61 F R+2.20$ DOC

$R_{s q}=77.57 \%$ and $R_{s q(a d j)}=64.12 \%$

Cutting Temperature $\left({ }^{\circ} \mathrm{C}\right)=1.9+0.1521 S S+158.3 F R-23.5 \mathrm{DOC}$

$R_{s q}=89.15 \%$ and $R_{s q(a d j)}=82.64 \%$

Machine Vibrations $\left(m / s^{2}\right)=-9.9+0.0065 S S+27.7 F R+26.3$ DOC

$R_{s q}=70.61 \%$ and $R_{s q(a d j)}=55.69 \%$

Machine Sound Levd $(d B)=62.1+0.0647$ SS + 85.0 FR - 11.47 DOC

$\mathrm{R}_{\mathrm{sq}}=88.57 \%$ and $\mathrm{R}_{\mathrm{sq}(\mathrm{adj})}=81.71 \%$

As shown in equations 8-15, it can be observed that the Rsq values of some responses are less than $80 \%$ which may be due to noise that results from experimental uncertainty [56].

\subsection{Contour plots.}

Contour plots for watermelon and mineral oils shown in Figure 5 were obtained using MINITAB 17 software to investigate the effect of change in two machining parameters when other parameters are kept constant under the flood cooling application technique.

Contour plots in Figure 5 revealed how a change in feed rate and spindle speed affects the performance of watermelon and mineral oils when the depth of cut is kept constant. Figures $5 \mathrm{a}$ and $5 \mathrm{~b}$ indicate that using watermelon and mineral oils, a surface finish of less than $3 \mu \mathrm{m}$ can be achieved using a spindle speed of $110 \mathrm{rev} / \mathrm{min}$ and a feed rate of $0.115 \mathrm{~mm} / \mathrm{rev}$, while Figure $5 \mathrm{c}$ and Figure $5 \mathrm{~d}$ revealed that cutting temperature of less than $50^{\circ} \mathrm{C}$ can be obtained using spindle speed of $450 \mathrm{rev} / \mathrm{min}$ and feed rate of $0.2 \mathrm{~mm} / \mathrm{rev}$ for watermelon oil as well as $400 \mathrm{rev} / \mathrm{min}$ spindle speed and $0.12 \mathrm{~mm} / \mathrm{rev}$ feed rate for mineral oil. 


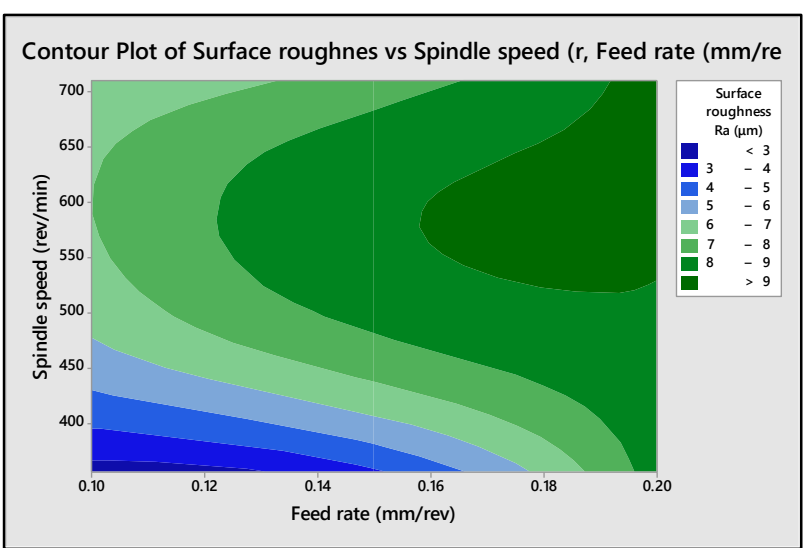

(a) Surface finish (watermelon oil)

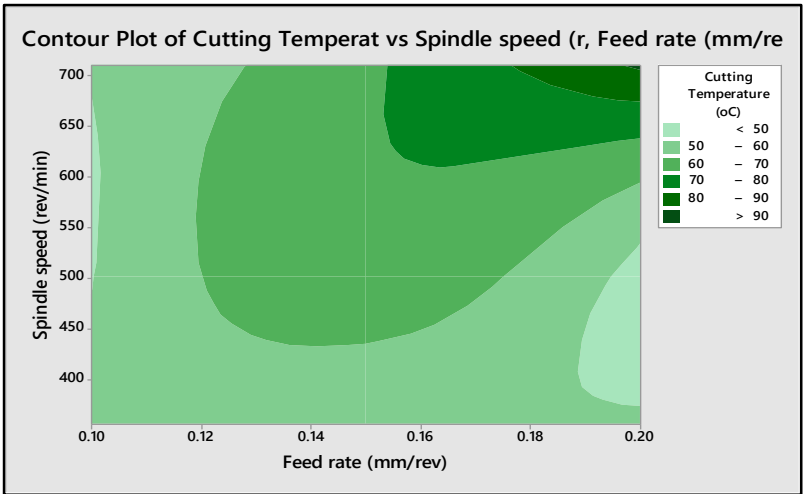

(c) Cutting temperature (watermelon oil)

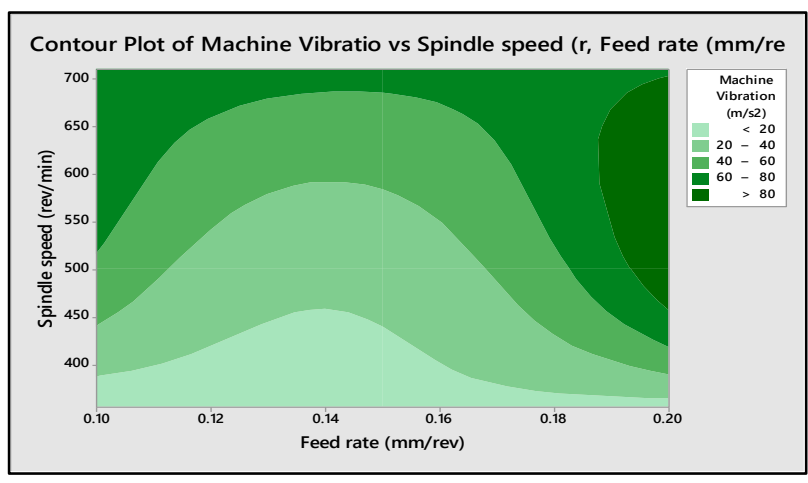

(e) Machine vibration (watermelon oil)

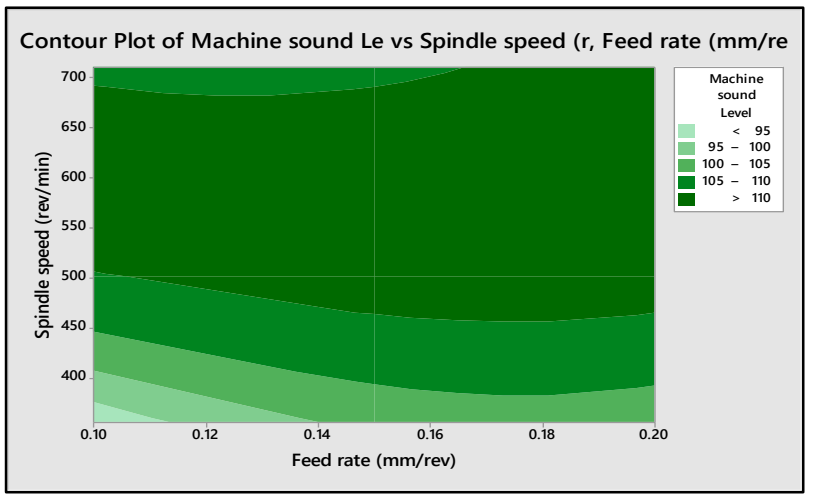

(g) Machine sound level (watermelon oil)

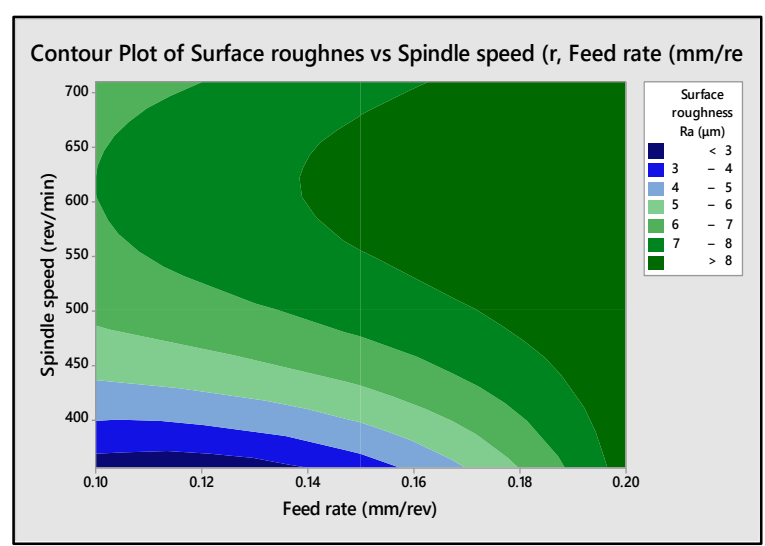

(b) Surface finish (mineral oil)

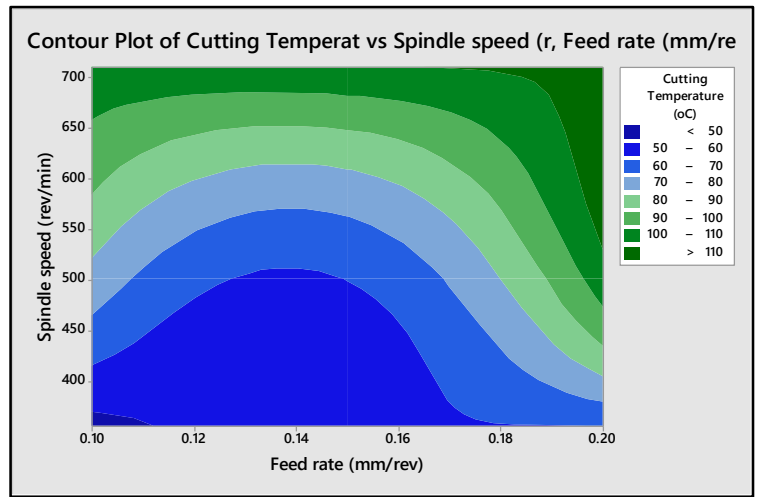

(d) Cutting temperature (mineral oil)

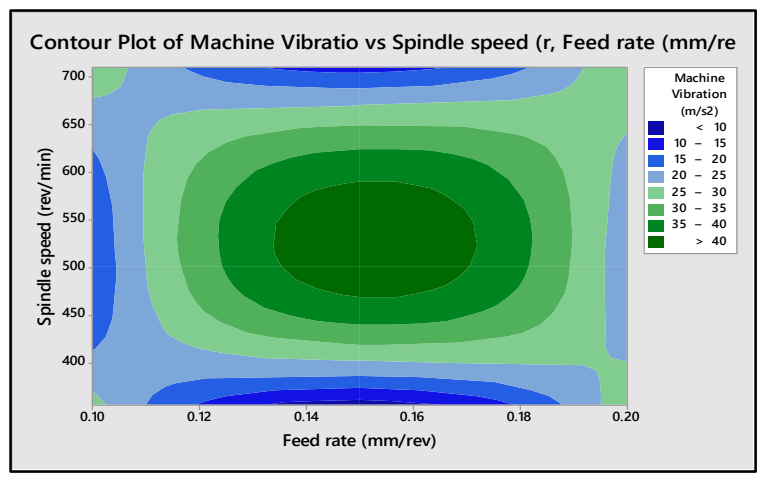

(f) Machine vibration (mineral oil)

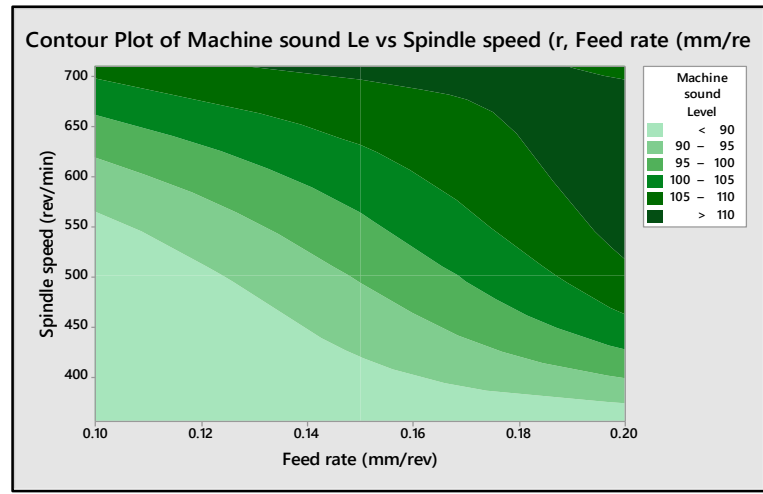

(h) Machine sound level (mineral oil)

Figure 5. Contour plots for watermelon and mineral oils. 
Similarly, Figure 5e and Figure 5f revealed that machine vibration of fewer than 20 $\mathrm{m} / \mathrm{s}^{2}$ (watermelon oil) and $10 \mathrm{~m} / \mathrm{s}^{2}$ (mineral oil) respectively could be achieved using a spindle speed of $80 \mathrm{rev} / \mathrm{min}$ and feed rate of $0.16 \mathrm{~mm} / \mathrm{rev}$, while Figure $5 \mathrm{~g}$ and Figure $5 \mathrm{~h}$ showed that machine noise level of fewer than 95 decibels for watermelon oil and 90 decibels for mineral oil could be achieved using spindle speed of $100 \mathrm{rev} / \mathrm{min}$ and feed rate of $0.1 \mathrm{~mm} / \mathrm{rev}$ and vice versa.

\subsection{Grey relational analysis.}

The GRA multi-response optimization process, as stated in the work of Aladesanmi et al. [56] and Agu et al. [44], involves the use of smaller-the-better parameters (equation 16) to measure the Grey Relational Generation (GRG) of individual responses using the S/N ratio values provided in Tables 11 and 12. This was accompanied by the Grey Relational Coefficient (GRC) estimation using equation 17. The last step of GRA was the use of equation 18 to measure the grey relational grade (GR-grade). Tables 17 and 18, respectively, demonstrate the GRA findings for watermelon oil-based cutting fluid and mineral oil-based cutting fluid.

For GRG, smaller-the-better,

$$
\left(d_{i j}\right)=\frac{\overline{t_{i j}}-t_{i j}}{\overline{t_{j}}-\underline{t}_{j}}
$$

$(i=1,2$, , $\mathrm{v}$ and $\mathrm{j}=1,2$,

Where, $\quad t_{i}=\left(t_{i 1}, t_{i 2}, \ldots \ldots \ldots, t_{i j}, \ldots . . . t_{i n}\right)$, $t_{i j}$ represents the performance value of alternative $i$ attribute $j$ and $\overline{t_{j}}=\max \left\{t_{i j}, i=1,2, \ldots \ldots . . v\right\}$ and $t_{\underline{j}}=\min \left\{t_{i j}, i=1,2, \ldots \ldots \ldots, v\right\}$

For GRC,

$$
\gamma\left(d_{o j}, d_{i j}\right)=\frac{\hbar_{\text {min }}+\eta \hbar_{\max }}{\hbar_{i j}+\eta \hbar_{\max }}
$$

$j=1,2, \ldots ., v$ and $i=1,2, \ldots ., u, \hbar_{i j}=d_{o j}-d_{i j}, \hbar_{\min }=\min \left(\hbar_{i j}, i=1,2, \ldots \ldots, v ; j=1,2, \ldots \ldots . . u\right)$, $\hbar_{\max }=\max \left(\hbar_{i j}, i=1,2, \ldots . . v ; j=1,2, \ldots . u\right)$ and $\eta$

The differentiating coefficient $\eta \in[0,1]$ is the one above. The distinction of the coefficient compresses or extends the grey correlation coefficient spectrum, and the generally accepted value is $0.5[39,57-58]$.

$$
G R \text { Grade }=\frac{\sum G R C}{\text { No of responses }}
$$

\begin{tabular}{|c|c|c|c|c|c|c|c|c|c|}
\hline \multirow{2}{*}{ Seq } & \multicolumn{3}{|c|}{ Grey Relational Generation (GRG) } & & \multicolumn{3}{|c|}{ Grey Relational Coefficient (GRC) } & & \multirow[t]{2}{*}{ Grade } \\
\hline & $R_{a}(\mu m)$ & $T\left({ }^{\circ} C\right)$ & $\mathrm{Ra}$ & $S(d B)$ & $R_{a}(\mu m)$ & $T\left({ }^{\circ} C\right)$ & $V\left(m / s^{2}\right)$ & $S(d B)$ & \\
\hline $\mathrm{X}_{0}$ & 1.000 & 1.000 & 1.000 & 1.000 & - & - & - & - & - \\
\hline 1 & 0.000 & 0.278 & 0.000 & 0.000 & 0.333 & 0.409 & 0.333 & 0.333 & 0.359 \\
\hline 2 & 0.312 & 0.121 & 0.343 & 0.470 & 0.421 & 0.363 & 0.432 & 0.485 & 0.405 \\
\hline 3 & 0.923 & 0.184 & 0.299 & 0.488 & 0.867 & 0.380 & 0.416 & 0.494 & 0.554 \\
\hline 4 & 0.698 & 0.095 & 0.822 & 0.843 & 0.623 & 0.356 & 0.737 & 0.760 & 0.572 \\
\hline
\end{tabular}

Table 17. GRG, GRC, and Grades of responses. 


\begin{tabular}{|c|c|c|c|c|c|c|c|c|c|}
\hline \multirow{2}{*}{ Seq } & \multicolumn{3}{|c|}{ Grey Relational Generation (GRG) } & & \multicolumn{3}{|c|}{ Grey Relational Coefficient (GRC) } & \multirow[b]{2}{*}{$S(d B)$} & \multirow{2}{*}{ Grade } \\
\hline & $R_{a}(\mu m)$ & $T\left({ }^{\circ} \mathrm{C}\right)$ & $\mathrm{Ra}$ & $S(d B)$ & $R_{a}(\mu m)$ & $T\left({ }^{\circ} \mathrm{C}\right)$ & $V\left(m / s^{2}\right)$ & & \\
\hline 5 & 0.908 & 0.494 & 0.562 & 0.918 & 0.845 & 0.497 & 0.533 & 0.859 & 0.625 \\
\hline 6 & 0.965 & 0.000 & 1.000 & 0.926 & 0.934 & 0.333 & 1.000 & 0.871 & 0.756 \\
\hline 7 & 0.685 & 0.130 & 0.919 & 0.804 & 0.614 & 0.365 & 0.860 & 0.719 & 0.613 \\
\hline 8 & 0.826 & 0.564 & 0.873 & 0.813 & 0.742 & 0.534 & 0.798 & 0.728 & 0.691 \\
\hline 9 & 1.000 & 1.000 & 0.929 & 1.000 & 1.000 & 1.000 & 0.875 & 1.000 & 0.958 \\
\hline
\end{tabular}

Table 18. GRG, GRC, and Grades of responses (mineral oil-based cutting fluid).

\begin{tabular}{l|l|l|l|l|l|l|l|l|l}
\multirow{2}{*}{ Seq } & \multicolumn{3}{|l}{ Grey Relational Generation $(\mathrm{GRG})$} & \multicolumn{2}{l}{ Grey Relational Coefficient (GRC) } & \multirow{2}{*}{ Grade } \\
\cline { 2 - 11 } & $\mathrm{Ra}$ & $\mathrm{T}\left({ }^{\circ} \mathrm{C}\right)$ & $\mathrm{V}\left(\mathrm{m} / \mathrm{s}^{2}\right)$ & $\mathrm{S}$ & $\mathrm{Ra}$ & $\mathrm{T}\left({ }^{\circ} \mathrm{C}\right)$ & $\mathrm{S}$ & & \\
\hline $\mathrm{Xo}$ & $\mathrm{Xo}$ & 1.000 & 1.000 & 1.000 & - & - & - & - & - \\
\hline 1 & 1 & 0.000 & 0.000 & 0.727 & 0.333 & 0.333 & 0.647 & 0.333 & 0.328 \\
\hline 2 & 2 & 0.261 & 0.230 & 0.000 & 0.404 & 0.394 & 0.333 & 0.335 & 0.283 \\
\hline 3 & 3 & 0.967 & 0.281 & 0.762 & 0.937 & 0.410 & 0.678 & 0.336 & 0.506 \\
\hline 4 & 4 & 0.718 & 0.566 & 0.398 & 0.640 & 0.535 & 0.454 & 0.333 & 0.407 \\
\hline 5 & 5 & 0.859 & 0.289 & 1.000 & 0.780 & 0.413 & 1.000 & 0.462 & 0.548 \\
\hline 6 & 6 & 1.000 & 0.933 & 0.589 & 1.000 & 0.882 & 0.549 & 0.861 & 0.608 \\
\hline 7 & 7 & 0.754 & 0.941 & 0.772 & 0.670 & 0.894 & 0.687 & 0.771 & 0.563 \\
\hline 8 & 8 & 0.890 & 0.973 & 0.289 & 0.820 & 0.949 & 0.413 & 1.000 & 0.545 \\
\hline 9 & 9 & 0.997 & 1.000 & 0.787 & 0.995 & 1.000 & 0.702 & 0.872 & 0.674
\end{tabular}

The resulting factors' effects of machining parameters obtained for watermelon oil and mineral oil using the grade values obtained from GRA as shown in Tables 17 and 18 are presented in Table 19 with values highlighted in bold indicating the optimal values of machining parameters. Similarly, the main effect plots for watermelon oil and mineral oil obtained using values given in Table 19 are shown in Figures 6 and 7, respectively.

Table 19. Resulting factor effects of machining parameters.

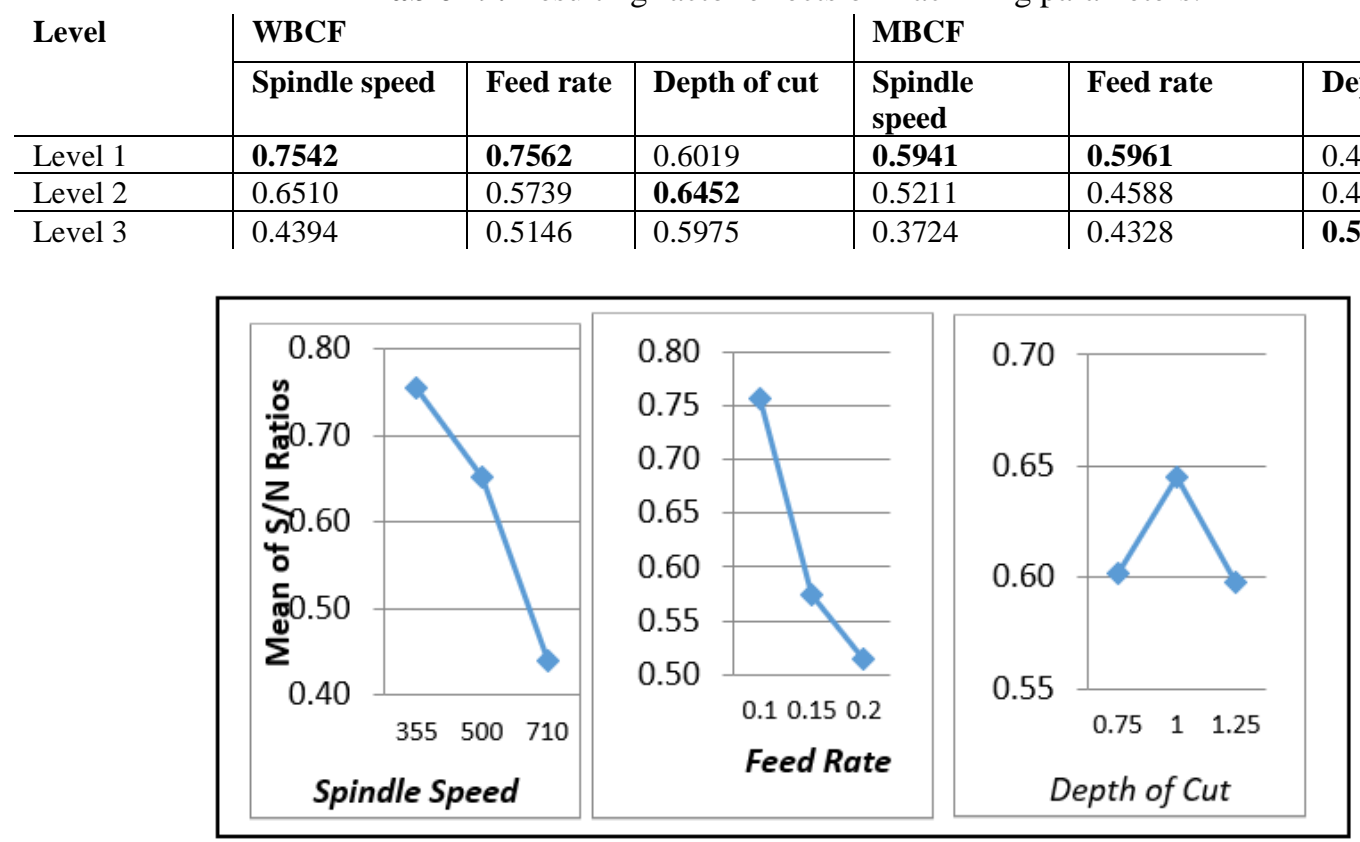

Figure 6. Parametric plots for WBCF.

The focus parametric plots for watermelon oil as cutting fluids shown in Figure 6 showed that the optimum multi-response machining output could be achieved with spindle velocity, feed rate as well as cutting depth of $355 \mathrm{rev} / \mathrm{min}, 0.1 \mathrm{~mm} / \mathrm{rev}$, and $1 \mathrm{~mm}$, respectively, while the focus parametric plots for mineral oil shown in Figure 7 predicted that optimum multi-response machining performance can be achieved using mineral oil. 


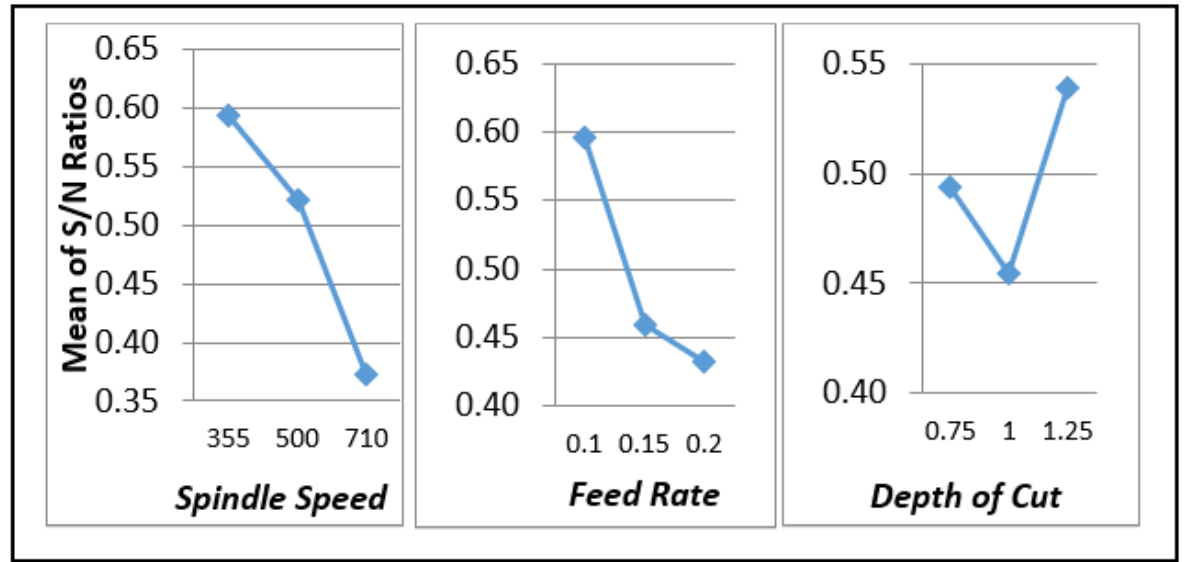

Figure 7. Parametric plots for MBCF.

Any change in the optimum values of these processing parameters can result in lowquality performance during the experimental process [11]. Also, empirical model equations shown in equations 8-15 were afterward utilized in finding the optimum values of machining performance for the formulated watermelon oil and commercially produced mineral oil using the optimal values of machining conditions (spindle speed, curing depth, as well as feed rate) obtained from GRA as represented in Figure 6 as well as Figure 7 respectively. The optimal response values shown in Table 20 were used in comparing the performance of watermelon and mineral oils.

Table 20. Optimal value responses.

\begin{tabular}{l|l|l} 
Re sponses & Watermelon oil & Mineral oil \\
\hline Machine vibration $\left(\mathrm{m} / \mathrm{s}^{2}\right)$ & 11.966 & 28.0525 \\
\hline Surface roughness $(\mu \mathrm{m})$ & 3.7621 & 4.1612 \\
\hline Machine sound level $(\mathrm{dB})$ & 92.706 & 79.231 \\
\hline Cutting temperature $\left({ }^{\circ} \mathrm{C}\right)$ & 45.263 & 42.3505
\end{tabular}

The multi-response performance results shown in Table 20 indicates that machining operation carried out using watermelon produced a better surface finish $(3.7621 \mu \mathrm{m})$ and lesser machine vibration $\left(11.966 \mathrm{~m} / \mathrm{s}^{2}\right)$ compared to that conducted using mineral oil which produced a surface roughness and machine vibration of $4.1612 \mu \mathrm{m}$ and $28.0525 \mathrm{~m} / \mathrm{s}^{2}$. Also, the cutting temperature and sound level produced by the use of the formulated watermelon oil $\left(45.263^{\circ} \mathrm{C}\right.$ and 92.706) are in good comparison with that of mineral oil $\left(42.3505^{\circ} \mathrm{C}\right.$ and 79.231$)$. These results revealed that the formulated watermelon oil could serve as a good substitute for mineral oil for use as cutting fluid in the machining operation, and this is in agreement with the works reported in [54-57].

\subsection{Analysis of chips development.}

The experiments performed under various cutting parameters and the development of chips after machining by cutting fluids are shown in Fig. 8. These chips are related to the ISO 3685 specifications and categorized.

Under various cutting scenarios and cutting fluids, the experiments were carried out. Following machining, the chips obtained are shown in Fig. 8. These chips are compared and graded according to the requirements of ISO 3685 [57]. The design of the chips obtained is shown to be various types of continuous chips with lengths varying from $3 \mathrm{~cm}$ to $15 \mathrm{~cm}$. 

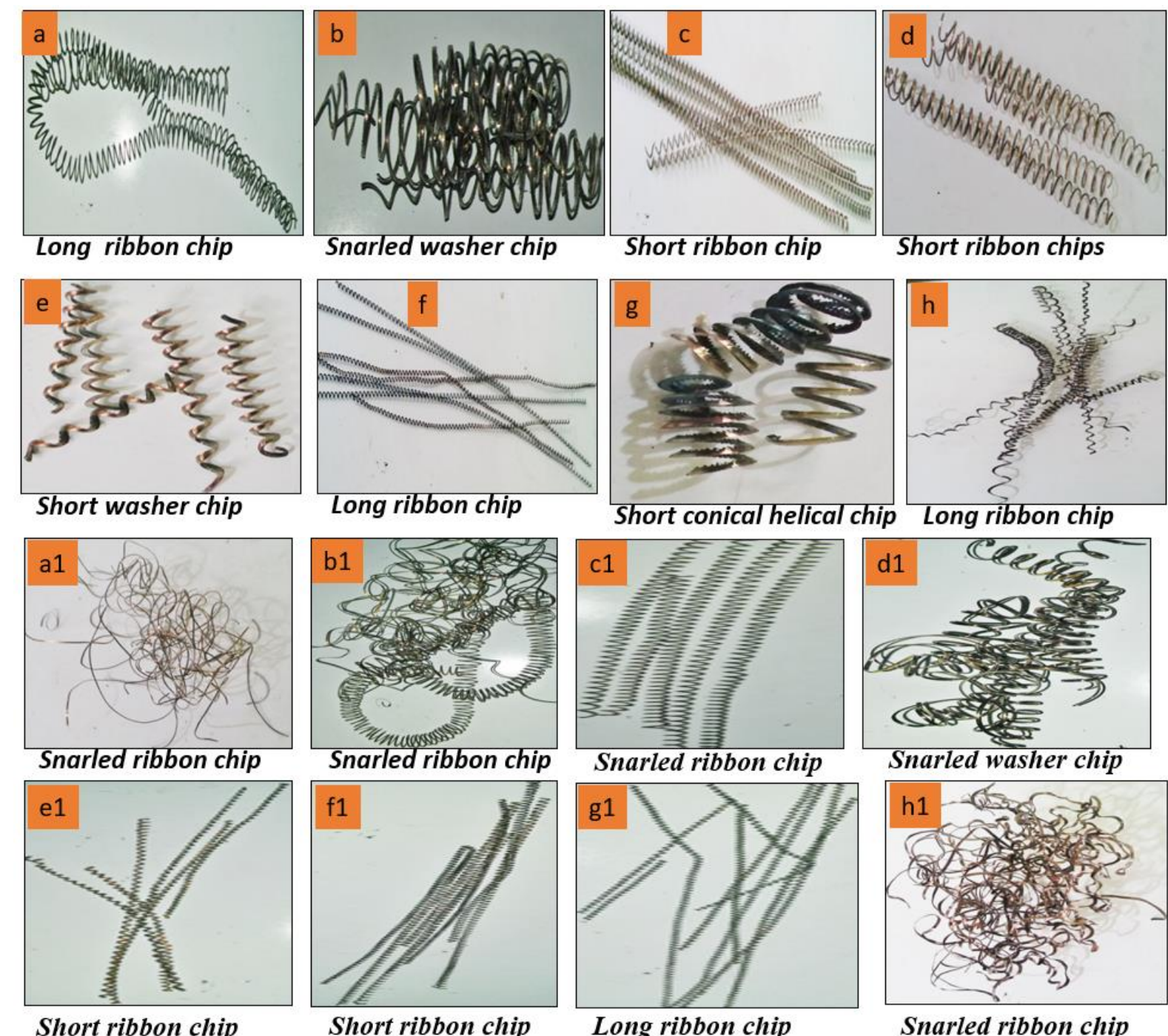

Short ribbon chip
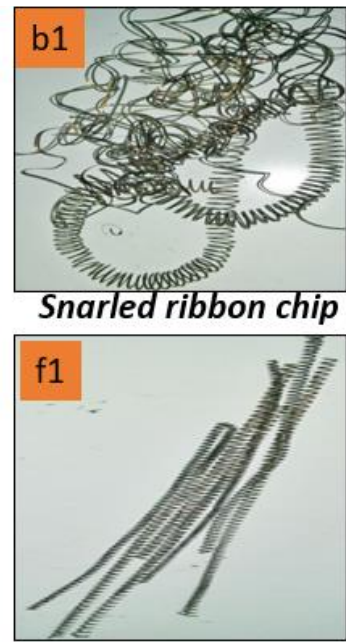

Short ribbon chip

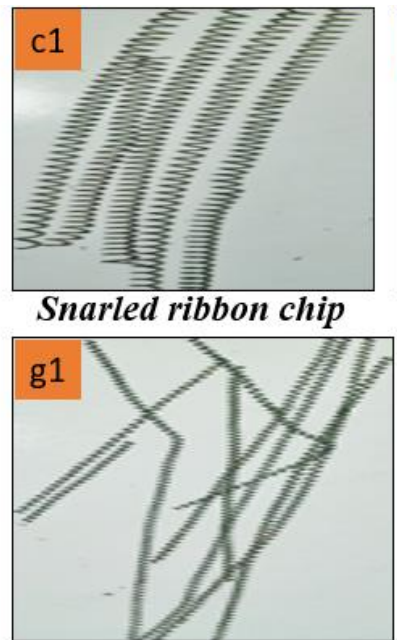

Long ribbon chip
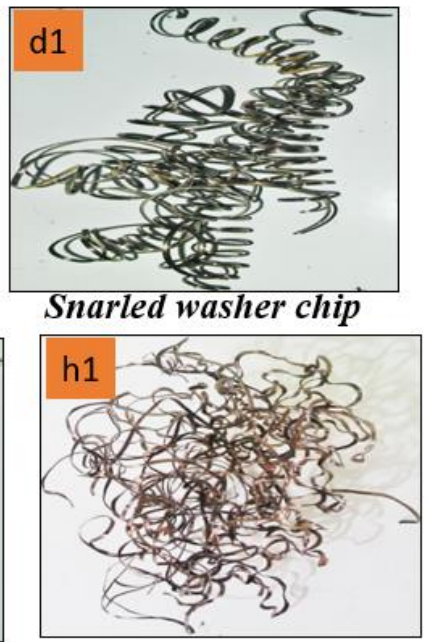

Snarled ribbon chip

Figure 8. Chip formation for (a-h) watermelon oil and (a1-h1) mineral oil.

The chips formed in the Watermelon emulsion cutting fluids machining and their numbers of occurrence are long ribbon (4), snarled washer (1), short ribbon (3), short washer (1), and short conical helical chips (1). Long ribbon and snarled washer are formed mostly at $0.75 \mathrm{~mm}$ depth of cut and irrespective of machining speed. The short ribbon is obtained at lower and higher spindle speeds. The short washer was therefore acquired at moderate speed and high cutting depth. In addition, while machining AISI 1525 steel with watermelon oil, short conical helical are shaped at high spindle speed and high cutting depth with a low feed rate. In five of the nine trials performed, mineral emulsion cutting fluids created mostly snarled ribbons. The snearled washer, short and long ribbon are among the chips that were formed. Due to various cutting parameters, multiple chips are formed; different normal and frictional forces at the interface of the tool and chip and different coefficients of friction produced at the interface of the chip and tool under different cutting fluid machining conditions [58-59].

Another way of evaluating chip morphology is the color of chips generated. After machining, two separate chip colors were observed: (i) the burnt and black chips and (ii) the light and smooth chips. Table 21 shows the analysis of chips' color produced. The burnt and black colored chips for the two cutting fluids indicate the temperature developed in the cutting zone was high. More than fifty percent of the watermelon samples produced bright and smooth chips. Mineral oil emulsion had only three samples with bright and smooth chips. The appearance of bright and smooth chips after metal cutting indicates that the surface roughness 
of the machined surface is less. The watermelon emulsion cutting fluids controlled the temperature at the cutting zone. This may be linked to the fact that watermelon oil had a great potential to penetrate the cutting region sufficiently than the mineral oil.

Table 21. Analysis of chips color produced.

\begin{tabular}{c|c|c}
\multirow{2}{*}{ Colour of chips } & \multicolumn{2}{|c}{ Type of emulsion cutting fluid } \\
\cline { 2 - 3 } & Watermelon oil & Mineral oil \\
\hline Burnt and black chips & $1,2,6,7$ & $2,3,4,5,6,7$ \\
\hline Bright and smooth chips & $3,4,5,8,9$ & $1,8,9$
\end{tabular}

\section{Conclusions}

In terms of its phytochemical, physicochemical, as well as lubricity characteristics, native Nigerian non-edible seed oil (watermelon seed) was sourced locally and studied. In turning AISI 1525 steel with a tungsten carbide plug, the performance evaluation of mineralbased cutting fluid and watermelon oil-based cutting fluid was investigated. From the results obtained and their discussions, the following conclusions can be drawn.

The results of gas chromatography-mass spectra (GCMS) showed that hexadecanoic acid was perhaps the most abundant form in watermelon oil, resulting in minimal skin cancer complications and respiratory problems, particularly acne, related to the use of mineral-based cutting fluids. This makes the watermen oil suitable as an application for cutting fluids. The fatty acids content in the extracted watermelon oils have tremendous usefulness and can be applied as a lubricant for lubricating purposes.

In addition, the viscosities of the watermelon oil and mineral oil-based cutting fluids were 1.6 Cst and 1.0 Cst, while their $\mathrm{pH}$ values were 9.7 and 8.5 , respectively. This means that the formulated cutting fluid falls within the appropriate amount necessary during the machining operation to remove corrosion and poses no health threat to employees. The analysis of variance results for watermelon and mineral oils showed that feed rate has the most significant impact on the surface roughness while cutting temperature and machine vibration are greatly affected by spindle speed, and depth of cut contributed the least impact on vibration of the machine.

The adequate multi-response efficiency of watermelon oil can be achieved using a spindle velocity of $355 \mathrm{rpm}$ (level 1), a feed rate of $0.1 \mathrm{~mm} / \mathrm{rpm}$ (level 1), and a cutting depth of $1 \mathrm{~mm}$ (level 2), whereas the optimum multi-response capacity of mineral oil can be obtained using a spindle velocity of $355 \mathrm{rpm}$ (level 1), a feed rate of $0.1 \mathrm{~mm} / \mathrm{rpm}$ (level 1) and a cutting depth of $1.25 \mathrm{~mm}$ (level 3).

Finally, all the turning experiments conducted on AISI 1525 steel workpiece using the two cutting fluids produced long continuous ribbon, snarled washer, short ribbon, short washer, and short conical helical chips, which are in compliance with the standards of ISO 3685.

\section{Funding}

This research received no external funding.

\section{Acknowledgments}

The authors are grateful for the support received from the Department of Mechanical Engineering, the University of Ibadan, to make use of the University Laboratories for this 
research work. The authors would like to express their gratitude to the anonymous reviewers for their insightful remarks and ideas for improving the quality of the paper.

\section{Conflicts of Interest}

The authors declared that there is no known conflict of interest.

\section{References}

1. Revankar, G.D.; Shetty, R.; Rao, S.S; Gaitonde, V.N. Analysis of surface finish and hardness in titanium alloy machining with polycrystalline diamond tool under different lubricating modes. Materials Research 2014, 17, 1010-1022, https://doi.org/10.1590/1516-1439.265114.

2. Sen, B.; Mia, M.; Mandal, U.K.; Mondal, S.P. Synergistic effect of silica and pure palm oil on the machining performances of Inconel 690: A study for promoting minimum quantity nano doped-green lubricants. Journal of Cleaner Production 2020, 258, 120755, https://doi.org/10.1016/j.jclepro.2020.120755.

3. Kıvak, T.; Sarıkaya, M.; Yıldırım, Ç.V.; Şirin, Ş. Study on turning performance of PVD TiN coated Al2O3+ TiCN ceramic tool under cutting fluid reinforced by nano-sized solid particles. Journal of Manufacturing Processes 2020, 56, 522-539, https://doi.org/10.1016/j.jmapro.2020.05.017.

4. Ibrahim, A.M.M.; Li, W.; Xiao, H.; Zeng, Z.; Ren, Y.; Alsoufi, M.S. Energy conservation and environmental sustainability during grinding operation of Ti-6Al-4V alloys via eco-friendly oil/graphene nano additive and MQL lubrication. Tribology International 2020, 150, 106387, https://doi.org/10.1016/j.triboint.2020.106387.

5. Gong, L.; Bertolini, R.; Ghiotti, A.; He, N.; Bruschi, S. Sustainable turning of Inconel 718 nickel alloy using MQL strategy based on graphene nanofluids. The International Journal of Advanced Manufacturing Technology 2020, 108, 3159-3174, https://doi.org/10.1007/s00170-020-05626-X.

6. Ozcelik, B.; Kuram, E.; Demirbas, E. Optimization of surface finish in drilling using vegetable-based cutting oils developed from sunflower oil. Industrial Lubrication and Tribology 2011, 63, 271-276, https://doi.org/10.1108/00368791111140486.

7. Margheritini, L.; Colaleo, G.; Contestabile, P.; Bjørgård, T.L.; Simonsen, M.E.; Lanfredi, C.; Dell'Anno, A.; Vicinanza, D. Development of an Eco-Sustainable Solution for the Second Life of Decommissioned Oil and Gas Platforms: The Mineral Accretion Technology. Sustainability 2020, 12, 3742, https://doi.org/10.3390/su12093742.

8. Ikumapayi, O.M.; Akinlabi, E.T.; Adedeji, P.A.; Akinlabi, S.A. Preparation, Characterization, Image Segmentation and Particle Size Analysis of Cow Bone Powder for Composite Applications. Trends in Manufacturing and Engineering Management, Lecture Notes in Mechanical Engineering 2021, 273-283, https://doi.org/10.1007/978-981-15-4745-4_25.

9. Krishna, P.V.; Srikant, R.R.; Rao, D.N. Experimental investigation on the performance of nanoboric acid suspensions in SAE-40 and coconut oil during turning of AISI 1040 steel. International Journal of Machine Tools and Manufacture, 2010; 50, 911-916, https://doi.org/10.1016/j.ijmachtools.2010.06.001.

10. Ojolo, S.J.; Ohunakin, O.S. Study of rake face action on cutting using palm- kernel oil as lubricant. Journal of Emerging Trends in Engineering and Applied Sciences (JETEAS) 2011, 2, 30-35.

11. Onuoha, O.J.; Abu, J.O.; Lawal, S.A.; Mudiare, E.; Adeyemi, M.B. Determining the effect of cutting fluids on surface finish in turning AISI 1330 alloy steel using Taguchi method. Modern Mechanical Engineering, 2016, 5, 51- 58, https://doi.org/10.4236/mme.2016.62006.

12. Rahim, E.A.; Sasahara, H. A study of the effect of palm oil as MQL lubricant on high speed drilling of titanium alloys. Tribology International 2011, 44, 309-317, https://doi.org/10.1016/j.triboint.2010.10.032.

13. Nurul-Adlina, M.J.; Kamaleshwaran, T.; AhamdFairuz, M.; Azwan, I. A. A study of surface finish \& surface integrity in drilling process using various vegetable-oil based lubricants in minimum quantity lubrication. Austr. J. Basic Appl. Sci. 2014, 8,191-197.

14. Fairuz, M.A.; Nurul-Adlina, M.J.; Azmi, A.I.; Hafiezal, M.R.M.; Leong, K.W. Investigation of chip formation and tool wear in drilling process using various types of vegetable-oil based lubricants. Applied Mechanics and Materials 2015, 799, 247-250, https://doi.org/10.4028/www.scientific.net/AMM.799800.247 .

15. Virdi, R.L.; Chatha, S.S.; Singh, H. Processing Characteristics of Different Vegetable Oil-based Nanofluid MQL for Grinding of Ni-Cr Alloy. Advances in Materials and Processing Technologies 2020, https://doi.org/10.1080/2374068X.2020.1800312. 
16. Faheem, A.; Husain, T.; Hasan, F.; Murtaza, Q. Effect of nanoparticles in cutting fluid for structural machining of Inconel 718, Advances in Materials and Processing Technologies 2020, https://doi.org/10.1080/2374068X.2020.1802563.

17. Rohit, S.G; Kupan, P. Experimental investigation of vegetable oil-based cutting fluid during turning of SS316L. International Journal on Mechanical Engineering and Robotics (IJMER) 2013, 1, 46-52.

18. Singh, H.; Sharma, V.S.; Dogra, M. Exploration of graphene assisted vegetables oil based minimum quantity lubrication for surface grinding of TI-6AL-4V-ELI. Tribology International 2020, 144, 106113, https://doi.org/10.1016/j.triboint.2019.106113.

19. Syed R.W.; Pervaiz, S.; Deiab, I. Tool wear patterns when turning of titanium alloy using sustainable lubrication strategies. International Journal of Precision Engineering and Manufacturing 2014, 15, 19791985, https://doi.org/10.1007/s12541-014-0554-z.

20. Sabahudin, E.; Begovic, E.; Ekinovic, E.; Fakic, B. Cutting forces and chip shape in MQL machining of aluminium bronze. Space 2013, 6, 6-10.

21. Ekinovic, E.; Begovic, E.; Prcanovic, H. MQL machining of difficult to cut materials. In 17th International Research/Expert Conference Trends in the Development of Machinery and Associated Technology, 2013, 4, 17-20.

22. Itoigawa, F.; Childs, T.H.C.; Nakamura, T.; Belluco, W. Effects and mechanisms in minimal quantity lubrication machining of an aluminum alloy. Wear 2006, 260, 339-344, https://doi.org/10.1016/j.wear.2005.03.035.

23. Deiab, I., Raza, S.W. and Pervaiz, S. Analysis of lubrication strategies for sustainable machining during turning of titanium Ti-6Al-4V alloy. Procedia CIRP $\mathbf{2 0 1 4}, \quad 17, \quad 766-771$, https://doi.org/10.1016/j.procir.2014.01.112.

24. Belluco, W.; De Chiffre, L. Performance evaluation of vegetable-based oils in drilling austenitic stainless steel. Journal of Materials Processing Technology 2004, 148, 171-176, https://doi.org/10.1016/S09240136(03)00679-4.

25. Ozcelik, B.; Kuram, E.; Cetin, M.H.; Demirbas, E. Experimental investigations of vegetable based cutting fluids with extreme pressure during turning of AISI 304L. Tribology International 2011, 44,1864-1871, https://doi.org/10.1016/j.triboint.2011.07.012.

26. Ozcelik, B.; Kuram, E.; Demirbas, E.; Ik, E. Effects of vegetable-based cutting fluids on the wear in drilling. Sadhana 2013, 38, 687-706, https://doi.org/10.1007/s12046-013-0179-4.

27. Ansari I.M.; Kotiveerachary B. Study of the effect of minimum quantity lubrication on surface finish of incoloy 800 during turning operation. International Journal of Mechanical Engineering \& Research 2013, 3 , 439-448, http://dx.doi.org/10.14741/ijcet/spl.2.2014.04.

28. Fernando, W.L.R.; Sarmilan, N.; Wickramasinghe, K.C.; Herath, H.M.C.M.; Perera, G.I.P. Experimental investigation of minimum quantity lubrication (MQL) of coconut oil-based Metal Working Fluid. Materials Today: Proceedings 2020, 23, 23-26, https://doi.org/10.1016/j.matpr.2019.06.079.

29. Kuram, E.; Simsek, B.T.; Ozcelik, B.; Demirbas, E.; Askin, S. Optimization of the cutting fluids and parameters using Taguchi and ANOVA in milling. Proceedings of the World Congress on Engineering 2010; $2,1-5$.

30. Shukla, A.; Kotwani, A.; Unune, D.R.. Performance comparison of dry, flood and vegetable oil based minimum quantity lubrication environments during CNC milling of Aluminium 6061. Materials Today: Proceedings 2020, 21, 1483-1488, https://doi.org/10.1016/j.matpr.2019.11.060.

31. Siti, A.A.; Yap, Y.L. Study the effect of vegetable-based lubricant on surface finish during milling operation by using response surface methodology. Applied Mechanics and Materials 2014, 548, 336-343, https://doi.org/10.4028/www.scientific.net/AMM.548-549.336.

32. Kumar, M.S.; Krishna, V.M.; Varun, A. Investigation on influence of Hybrid Biodegradable Nanofluids (CuO-ZnO) on Surface Roughness in Turning AISI 1018 Steel. Materials Today: Proceedings 2020, 24, 1570-1576, https://doi.org/10.1016/j.matpr.2020.04.477.

33. Papiya, B.; Gaurav, A.; Nitesh, P.; Nitin, B. Improving the surface texture of mild steel using vegetable oil as cutting fluid. International Journal of Applied Engineering Research 2014, 9, 883-888.

34. Susmitha, M.; Sharan, P.; Jyothi, P.N. Influence of non-edible vegetable based oil as cutting fluid on chip, surface finish and cutting force during drilling operation of Mild Steel. IOP Conference Series: Materials Science and Engineering 2016, 149, 012037. 
35. Lawal, S.A.; Choudhury, I.A.; Nukman, Y. Evaluation of vegetable and mineral oil-in-water emulsion metal cutting fluids in turning AISI 4340 steel with coated carbide tools. Journal of Cleaner Production 2014, 66, 610-618, https://doi.org/10.1016/j.jclepro.2013.11.066.

36. Sachin A.M.; Lahane, S.; Patil, N.G.; Brahmankar, P.K. Experimental investigations into wear characteristics of M2 steel using cotton seed oil. Procedia Engineering 2014, 97, 4-14, https://doi.org/10.1016/j.proeng.2014.12.218.

37. Ojolo, S.; Amuda, M.; Ogunmola, O.; Ononiwu, C. Experimental determination of the effect of some straight biological oils on cutting force during cylindrical turning. Materia 2008, 13, 650-663, https://doi.org/10.1590/S1517-70762008000400011.

38. Majak, D.; Olugu, E.U.; Lawal, S.A. Analysis of the effect of sustainable lubricants in the turning of AISI 304 stainless steel. Procedia Manufacturing $\quad \mathbf{2 0 2 0}, \quad 43, \quad 495-502$, https://doi.org/10.1016/j.promfg.2020.02.183.

39. Chinchanikar, S.; Salve, A.V.; Netake, P.; More, A.; Kendre, S.; Kumar, R. Comparative evaluations of surface finish during hard turning under dry and with water-based and vegetable oil-based cutting fluids. Procedia Materials Science 2014, 5, 1966-1975, https://doi.org/10.1016/j.mspro.2014.07.529.

40. Kumar, M.S.; Krishna, V.M. An Investigation on Turning AISI 1018 Steel with Hybrid Biodegradeable Nanofluid/MQL Incorporated with Combinations of CuO-Al2O3 Nanoparticles. Materials Today: Proceedings 2020, 24, 1577-1584, https://doi.org/10.1016/j.matpr.2020.04.478.

41. Satheesh, K.; Padmanabhan, G.; Vamsi, P.; Krishna . Experimental investigations of vegetable oil based cutting fluids with extreme pressure additive in machining of AISI 1040 steel. Manufacturing Science and Technology 2015, 3, 1-9, https://doi.org/10.13189/mst.2015.030101.

42. Shashidhara, Y.M.; Jayaram, S.R. Vegetable oils as a potential cutting fluid - an evolution. Tribology International 2010, 43, 1073-1081, https://doi.org/10.1016/j.triboint.2009.12.065.

43. Shashidhara, Y.M.; Jayaram, S.R. Experimental determination of cutting power for turning and material removal rate for drilling of AA 6061-T6 using vegetable oils as cutting fluid. Advances in Tribology 2013, 2013, 362931, https://doi.org/10.1155/2013/362931.

44. Alves, S.M.; De Oliveira, J.F.G. Development of new cutting fluid for grinding process adjusting mechanical performance and environmental impact. Journal of Materials Processing Technology 2006, 779, 185-189, https://doi.org/10.1016/j.jmatprotec.2006.03.090.

45. Mayurkumar, A.; Kaushik, M.; Patel, M. Improvement in machining process performance using solid lubricant assisted minimum quantity lubrication, Advances in Materials and Processing Technologies 2021, https://doi.org/10.1080/2374068X.2021.1882123.

46. Association of Official Analytical Chemists. Official Methods of Analysis, 14th Edition, Arlington, USA, 1984, 67, 503 515 .

47. Muniz, C.A.S.; Dantas, T.N.C.; Moura, E.F.; Neto, A.D.; Gurgel, A. Novel formulations of cutting fluids using naphtenic basic oil. Brazilian Journal of Petroleum and Gas 2009, 2, 1-14.

48. Mahalle, G.; Kotkunde, N.; Gupta, A.K.; Singh, S.K. Prediction of flow stress behaviour by materials modelling technique for Inconel 718 alloy at elevated temperature, Advances in Materials and Processing Technologies 2020, 6, 376-383, https://doi.org/10.1080/2374068X.2020.1728649.

49. Eze, S.O.O. Physico-chemical properties of oil from some selected underutilized oil seeds available for biodiesel preparation. African Journal of Biotechnology 2012, 11, 10003-10007.

50. Oderinde, R.A.; Ajayi, I.A.; Adewuyi, A. Characterization of seed and seed oil of Huracrepitans and the kinetics of degradation of the oil during heating. Electron. J. Environ. Agric. Food Chem. 2009, 8, 201-208.

51. Oyinbo, S.T.; Ikumapayi, O.M.; Jen, T.C.; Ismail, S.O. Experimental and Numerical prediction of extrusion load at different lubricating conditions of aluminium 6063 alloy in backward cup extrusion. Engineering Solid Mechanics, 2020, 8, 119-130. https://doi.org/10.5267/j.esm.2019.10.

52. Letawe, C.; Boone, M.; Pierard, G.E. Digital image analysis of the effect of topically applied linoleic acid on acne microcomedones. Clinical and experimental dermatology 1998, 23, 56-58, https://doi.org/10.1046/j.1365-2230.1998.00315.x.

53. Ikumapayi, O.M.; Oyinbo, S.T.; Bodunde, O.P.; Afolalu, S.A.; Okokpujie, I.P.; Akinlabi, E.T. The effects of lubricants on temperature distribution of 6063 aluminium alloy during backward cup extrusion process. $J$ Mater Res Technol. 2019, 8, 1175 -1187, https://doi.org/10.1016/j.jmrt.2018.08.006.

54. Singh, Y.; Sharma, A.; Singh, N.K.; Singla, A.; Kumar, R. Moringa Oleifera: Bio based lubricant development from a novel feedstock for tribological characterization, Advances in Materials and Processing Technologies 2020, https://doi.org/10.1080/2374068X.2020.1829956. 
55. Caudill, J.; Schoop J.; Jawahir, I. S. Correlation of surface integrity with processing parameters and advanced interface cooling/lubrication in burnishing of Ti-6Al-4V alloy, Advances in Materials and Processing Technologies 2019, 5, 53-66, https://doi.org/10.1080/2374068X.2018.1511215.

56. Abutu J.; Lawal S.A.; Ndaliman M.B.; Lafia-Araga R.A.; Adedipe O.; Choudhury I.A. Effects of process parameters on the properties of brake pad developed from seashell as reinforcement material using grey relational analysis, Engineering Science and Technology, an International Journal 2018, 21, 787-797, https://doi.org/10.1016/j.jestch.2018.05.014.

57. Aladesanmi, V.I.; Fatoba O.S.; Akinlabi E.T.; Ikumapayi O.M. Analysis of wear properties and surface roughness of laser additive manufactured (LAM) Ti and TiB2 metal matrix composite. Material today: Proceedings 2021, 44, 1279-1285, https://doi.org/10.1016/j.matpr.2020.11.266.

58. Pal, A.; Chatha, S.S.; Sidhu, H.S. Experimental investigation on the performance of MQL drilling of AISI 321 stainless steel using nano-graphene enhanced vegetable-oil-based cutting fluid. Tribology International 2020, 151, 106508, https://doi.org/10.1016/j.triboint.2020.106508.

59. Xavior, M.A.; Adithan, M. Determining the influence of cutting fluids on tool wear and surface finish during turning of AISI 304 austenitic stainless steel. Journal of materials processing technology 2009, 209, 900909, https://doi.org/10.1016/j.jmatprotec.2008.02.068. 